\title{
Reef fish community structure in the Tropical Eastern Pacific (Panamá): living on a relatively stable rocky reef environment
}

\author{
Arturo Dominici-Arosemena $\cdot$ Matthias Wolff
}

Received: 12 September 2005/ Revised: 2 May 2006/ Accepted: 3 May 2006/ Published online: 14 June 2006

(C) Springer-Verlag and AWI 2006

\begin{abstract}
We compared the community structure of reef fish over different physical complexities in 12 study zones of Bahía Honda, Gulf of Chiriquí (BHGCH), Tropical Eastern Pacific (TEP), Panama, aiming at an analysis of the importance of the physical structure provided by corals, rocks and benthic sessile organisms. This was the first region that emerged in the Isthmus of Panama; it exhibits the oldest benthic fauna and has constant conditions in terms of temperature and salinity. Two hundred and eighty-eight visual fish censuses were conducted on 48 benthic transects from February to July 2003. One hundred and twenty-six fish species of 44 families were found. Plankton feeding pomacentrids and labrids along with haemulids that feed on mobile invertebrates were the most abundant, particularly in shallow areas. Fourteen species showed size-segregations between zones, suggesting ontogenetic migrations (smaller fishes in shallow high-complexity zones, larger-sized fishes in deeper habitats). Highly mobile and site-attached genera were abundant in most shallow, wave-exposed zones particularly on exposed rocky substrates. Planktivores were the most abundant, followed by carnivores, feeders on mobile invertebrate and piscivores. Herbivores and feeders on sessile invertebrate were lower in abundance. Species richness exceeds that of any other studied region close to the mainland in the TEP and correlates with substrate diversity, increasing size-heterogeneity of holes
\end{abstract}

Communicated by H.-D. Franke

A. Dominici-Arosemena $(\triangle) \cdot$ M. Wolff

Centre for Tropical Marine Ecology (ZMT),

Fahrenheitstrasse 6, 28359 Bremen, Germany

e-mail: dominici@uni-bremen.de and structural complexity. Species diversity increases with habitat complexity and benthic diversity. It seems that water current strength, tides and waves which select for swimming, play an important role in the community organization. The study region has been proposed as a refuge-centre in the TEP, where reef fishes that evolved on coral reefs have shifted their distribution onto rocky reef habitats.

Keywords Fish diversity - Distribution - Trophic groups $\cdot$ Rocky reef $\cdot$ Tropical Eastern Pacific

\section{Introduction}

Ocean basins may promote speciation within a region during periods of low sea levels, and extensive shallow habitats can reduce faunal losses by acting as a refuge or centre of accumulation (Springer and Williams 1994; Paulay 1996; Wilson and Rosen 1998; Palumbi 1997; Bellwood and Hughes 2001). It has been suggested that reef fish have evolved along with the coral communities they are associated with, but that their ancestors have existed even prior to the coral reefs (Bellwood and Wainwright 2002). Thus, the recent reef dwellers would represent derived forms, with ancestors which would have occupied non-reef habitats (Bellwood and Wainwright 2002). In this respect, it should be considered that tropical reef fishes indeed occupy noncoral built habitats such as rocky shores that are predominant in the Tropical Eastern Pacific (TEP). The fish fauna in this region has a north-south division, and subdivisions can be based on the highly localized endemism of small benthic rocky reef-associated fishes (Hastings and Robertson 2001). In the Central American 
Isthmus, besides the Golfo Dulce in Costa Rica, a fiord-like tropical embayment with anoxic deep waters (Quesada-Alpízar and Morales-Ramírez 2004; Wolff et al. 1996) and low coral development (Cortés 1990), the first uplifted region where new reef development started is the open area of the Gulf of Chiriquí $(\mathrm{GCH})$. Here are the oldest corals of modern reefs in the TEP displaying maximum thickness and accretion rates (Cortés 1993, 1997). This region comprises the largest archipelago of rocky islands in the TEP (Kwiecinski and Chial 1983; Glynn and Maté 1997). Due to its inaccessibility, detailed biological studies are still lacking. The fish community structure of this region is particularly interesting from the perspective of population biology and biogeography due to its geological history and environmental stability (Kwiecinski and Chial 1983; Glynn and Maté 1997). The GCH forms part of the Panamic province of the TEP, and there is only one recent inventory in the Coiba National Park by Vega and Villarreal (2003), which includes many reef fish with the exception of the cryptic ones (e.g. gobiids, chaenopsids). Some pioneering studies have already addressed variations of the reef fish community structure in the reef areas in TEP (Zapata and Morales 1997; Arburto-Oropeza and Balart 2001; DominiciArosemena et al. 2005). Belonging to the lower Mesoamerica, this region offers unique opportunities for comparative fish community studies (e.g. non-reef vs. coral reef environments; TEP vs. Tropical Western Atlantic, TWA) (Robertson 1998). It is believed that this region has a very diverse fish fauna, and that a significant component of it is made up of resident transpacific fishes that may live on reefs elsewhere in the Pacific (Robertson 1998). There is a sufficient diversity of habitats allowing for meaningful biological comparisons with the lower Mesoamerican TWA.

For comparative purposes we have conducted recently a similar study on the Caribbean west side of the Isthmus in Bocas del Toro (Dominici-Arosemena and Wolff 2005). Both the Caribbean and the Pacific side of Western Panama exhibit a rich landscape, and it was these parts, which in geologic times (7-3 million years ago) became first interconnected by a shallow shelf (while Eastern Panama was still lacking a shelf area) when the isthmus started to rise, finally resulting in the fusion of the North and South American continents and the separation of the two oceans (Bermingham et al. 1997).

While the Indo-Pacific regions have been suggested as evolutionary source of many reef fish species worldwide (Mora et al. 2003), the TWA is believed to be the centre of diversity for both fish and corals in the Atlantic Ocean (Briggs 1995; Veron 1995; Floeter and
Gasparini 2000). However, the available information on the TEP does not allow for the determination of gradients in fish diversity in the Mesoamerican region and for the verification of the basic assumption of higher diversity of reef fish in the TWA compared to the TEP.

The main objective of the present study was thus to characterise the fish assemblages of Bahía Honda (BHGCH, TEP) along spatial scales and gradients of substrate complexity.

It is hypothesized that due to its environmental stability (as compared to other TEP regions), its relative old age and great habitat diversity, a relatively rich reef fish community has evolved. Since this and other regions of the TEP have been subjected to a massive decrease in coral diversity due to geological changes, we suspect that reef fish may have evolved and diversified on the available rocky substrates with high benthic diversity and complexity in a similar way as have other reef fish communities on (diverse) coral reefs elsewhere. We thus propose that corals do not play the same reef community-structuring role here as in the Indo-Pacific and the Caribbean, and we postulate that reef fish communities may just represent species guilds related to hard substrates of diverse complexity.

The TEP region is the most unstable province in the whole Pacific where reef communities are adapted to geological changes, and to temperature decreases due to coastal upwelling. In the non-upwelling $\mathrm{GCH}$ (where temperatures are higher with relatively low seasonality) fishes and benthic fauna that recruit from more unstable regions may be adapted to short scale disturbances, particularly warming events (e.g. ENSO; for disturbance resistance in corals on this region, see $\mathrm{D}^{\prime} \mathrm{Croz}$ and Maté 2004). Even though research is pending in this field, the fishes in GCH, TEP may have developed some resistance to environmental changes, and suitable habitats should have promoted their speciation and diversification in the region.

The study thus aims at an analysis of the relative importance of the physical structure provided by corals, rocks and benthic sessile organisms for the reef fish community organization.

Furthermore, we studied the coexistence of subordinate species with dominant species by differential habitat use (i.e. different mobility and home range, size frequencies, territoriality, trophic organization), the importance of wave exposure and current regime for structuring the community, and the role of reef type (i.e. coral reefs vs. rocky reefs) and general substrate diversity and complexity for shaping the fish community. 


\section{Materials and methods}

Study area

The Pacific coast of Panama is divided by the Azuero Peninsula into two major areas with notable oceanographic differences: the upwelling Gulf of Panama to the East and, protected from northern trade winds by the mountains, the non-upwelling stable $\mathrm{GCH}$ to the West (D'Croz and Robertson 1997; Glynn and Maté 1997). Study sites were located in the latter $\left(7^{\circ} 50^{\prime} \mathrm{N}\right.$, $81^{\circ} 35^{\prime} \mathrm{W}$; Fig. 1). Sampling was carried out from February to July 2003.

The GCH has a rainy climate compared to the Gulf of Panama. The coverage of living coral decreases with depth due to an increase in turbidity, and the region has large tidal variations of up to 3-4 m (Glynn and Maté 1997; NOOA/NOS 2006). There are fringing pocilloporid patch reefs over rocks between $\mathrm{BH}$ and

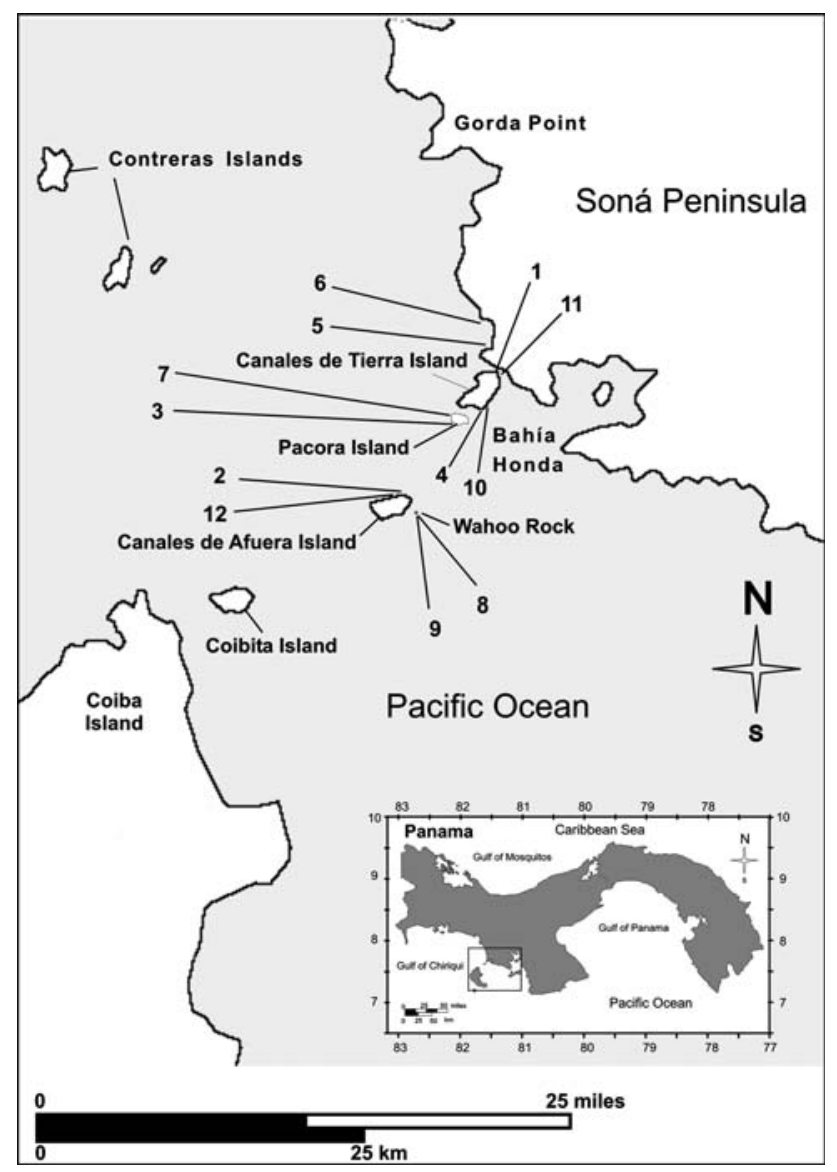

Fig. 1 Sampled reef zones in Bahía Honda, Gulf of Chiriquí. 1 Isla Canales de tierra; 2 Canales de Afuera; 3 Isla Pacora; 4 Bonsai key; 5 Isla Mona; 6 Punta Gorda; 7 Isla Pacora; 8 Wahoo Rock key; 9 Wahoo rock; 10 Bonsai Cay; 11 Isla Canales de tierra; 12 Isla Canales de afuera other regions close to the mainland. Coral and rocky reefs are present also off shore on the Canales de Afuera Island, which is part of the Coiba National Park (Cardiel et al. 1997).

Twelve study zones were classified in terms of depth, substrate topography, cover, kind of benthic organisms and inorganic substrates. The selection of study zones was based on a previous survey aimed at identifying areas of different but characteristic habitats of the region.

\section{Habitat characterisation}

In each of the 12 zones, 4 benthic transects of $30 \mathrm{~m}$ length each were set up parallel to the shore. Substrate coverage and surface complexity was estimated using a link-chain methodology (CARICOMP 2001; Rogers et al. 1994). The benthic surface measures were taken along the chain laid out limp to follow the surface contour of the substrate. The ratio between the length of the chain laid over the substrate and the direct linear length from the beginning to the end of each transect was used to estimate the structural complexity of the substrate. The type of substrate under each segment of the chain was recorded and the length of the contour for each portion was then estimated as $1.6 \mathrm{~cm}$ per chainlink. Following Ferreira et al. (2001) we considered the number and size of holes as an additional complexity variable. For this, we counted the holes present along both sides of each transect $(2.5 \mathrm{~m})$ on all types of habitats and measured their size with a PVC ruler.

Habitat structure

A detailed description of the coral composition of the region can be found in Glynn and Maté (1997). The substrate codes assigned for substrate categories are found in Table 1, and according to the indexes obtained for surface complexity, we classified the zones as follows: 1-3 low complexity, 4-6 intermediate, and 712 high complexity (Fig. 2).

Sand and rubble (SRU; 1-2): Found in deeper areas adjacent to patches of the branching coral Pocillopora sp., and with a mixture of dead pieces of coral and sand.

Deep zone of middle size rocks and sand (DRS; 3$)$ : A mixture of middle size rocks (around $30-50 \mathrm{~cm}$ ) covered by fleshy algae of the genus Padina, encrusting-turf red algae and sand.

Deep rocky wall ( $D R W ; 4)$ : Rock walls covered by encrusting red algae and some small colonies of erect and encrusting sponges. Vertical crevices were also present. 
Table 1 Substrate codes

\begin{tabular}{ll}
\hline Code & Category \\
\hline BDC & Branching dead corals \\
DMC & Dead massive corals \\
DYC & Dictyota spp. \\
EBA & Rock-encrusting brown algae \\
EC & Rock-encrusting corals \\
ERA & Rock-encrusting red algae \\
ECS & Rock-encrusting sponges \\
ES & Erect sponges \\
FBA & Fleshy brown algae (Padina spp.) \\
FRADBC & Fleshy red algae/dead branching corals \\
MC & Massive corals \\
PD & Pocillopora damicornis \\
PE & Pocillopora elegans \\
BRIO & Rock-bryozoans \\
RU & Rubble \\
RUEA & Rubble-encrusting red algae \\
RFRA & Rubble fleshy red algae \\
TBA & Turf brown algae \\
TCA & Turf calcareous algae \\
TCRA & Turf-calcareous red algae \\
TRA & Turf red algae \\
\hline
\end{tabular}

Deep rocky reef $(D R ; 8)$ : Continuous rocky zones exposed to oceanic currents. It is similar to DRW, but DR has more heterogeneous complex rocks and more sand, and is partially covered by fleshy brown algae of the genus Sargassum and calcareous red algae Galaxaura.

Exposed shallow rocky reef (SR; 7-9-10): Rocky shallow reefs that are strongly wave-exposed and harbour living colonies of the scleractinian corals Pocillopora elegans and $P$. damicornis; they are tightly covered by encrusting, turf and calcareous red algae along with turf brown algae of the genus Dictyota. These zones feature numerous cavities and crevices.

Zones of massive coral (MCR; 5-6): Coral-reef zones separated by sand, with a mixture of living and dead massive coral of two different genera including Pavona gigantea and Porites lobata; also turf brown algae, rubble and sand. These zones feature many crevices.

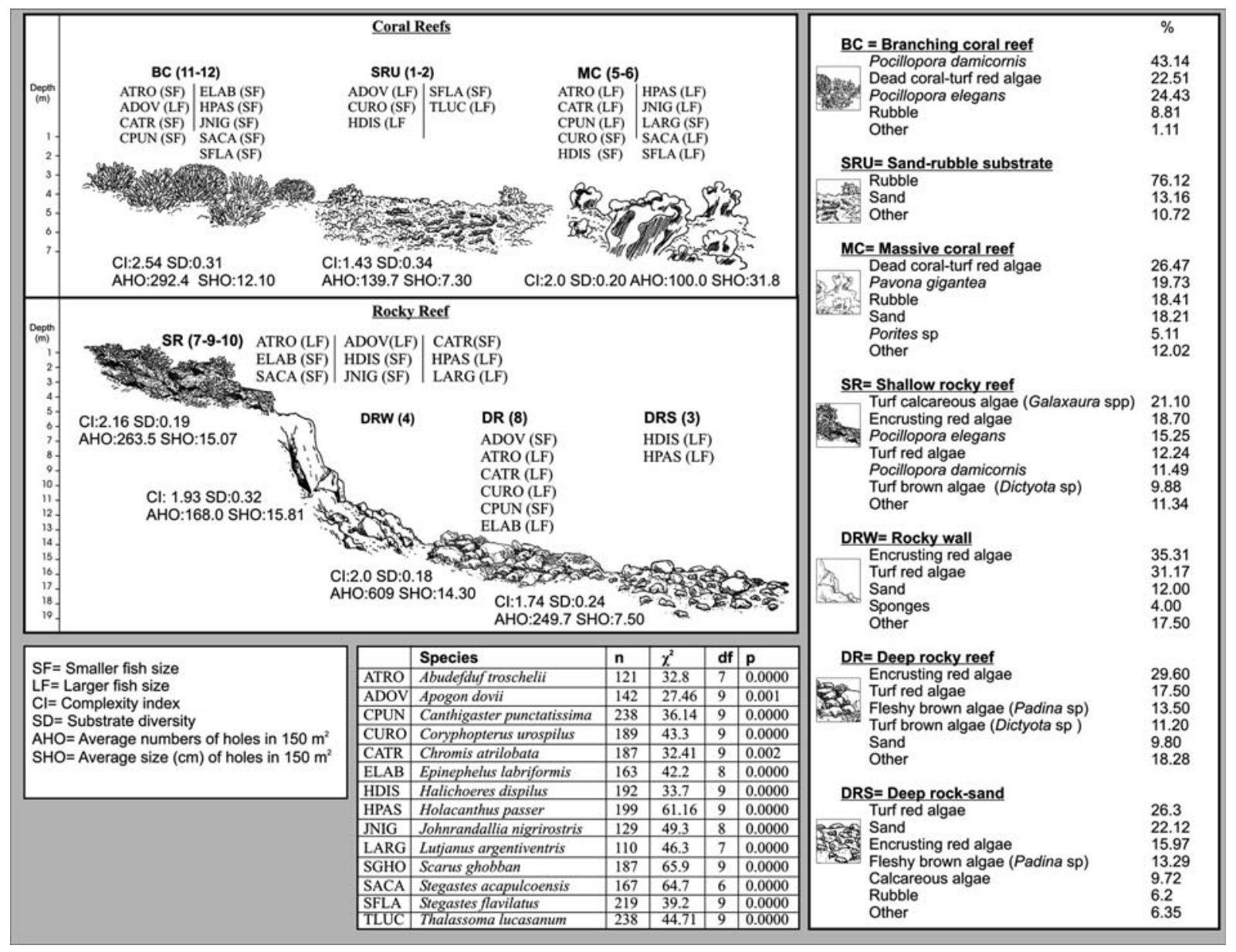

Fig. 2 Summary of habitat structure variables and results of the frequency analysis $\left(\chi^{2}\right)$ to test for habitat-related differences in the size distribution of species; only species that had significant differences in size are shown 
Zones of madreporic branching coral (BCR; 11-12): Patchy zones dominated by the branching corals $\mathrm{Po}$ cillopora damicornis and P. elegans, and characterised by an absence of rocks.

\section{Estimation of fish abundance}

The species of fish present and their abundance was assessed using standard methodology for underwater visual surveys with SCUBA diving equipment, e.g. English et al. (1994). The fixed transects used for the study of the benthos were also used for the fish censuses $(30 \times 5 \mathrm{~m})$. Monthly sampling was conducted at all transects (six censuses per transect). A total of 288 visual censuses were conducted on 48 benthic transects. Three same observers during the whole study period swam along the transects, recording data for fishes (including small cryptic individuals) encountered within $2.5 \mathrm{~m}$ on both sides and $5 \mathrm{~m}$ above for $45 \mathrm{~min} /$ transect. The standard length (SL) of the fishes was estimated to the nearest $\mathrm{cm}$ with a PVC ruler. From these data, abundance (individuals $/ 150 \mathrm{~m}^{2}$ ) and Shannon-Wiener diversity $\left(H^{\prime}\right)$ were calculated based on relative abundance (Pielou 1975).

Spatial use, mobility and trophic groups

Each species was included in one of three mobility and home range size categories, as applied by Floeter et al. 2004: Category 1 = wide horizontal displacement, high mobility; category $2=$ sedentary and demersal species in close association with the substrate; category $3=$ small home range and a side attachment and/or territorial behaviour.

Fish species were classified trophically according to Ferreira et al. (2004) as carnivores (fish that feed on mobile benthic organisms and fish); mobile-invertebrate feeders (fish that feed primarily on crabs, molluscs and other benthic mobile invertebrates on hard and soft substrates); omnivores (fishes that feed on a variety of organisms, including both animal and plant material); piscivores (fishes that prey on living fishes); planktivores (fish that consume primarily macro- and micro-zooplankton); roving herbivores (fish that feed on detritus, turf algae and macroalgae, e.g. scarids and acanthurids); sessile-invertebrate feeders (fish that eat sessile benthic invertebrates); territorial herbivores (fish that feed on farmed turf-algae within their territories).

\section{Data analysis}

Simpson's diversity index was used to estimate the diversity of organic (e.g. corals, algae) and inorganic (bare rocks, sand-rubble) habitat categories (modified classification from Ferreira et al. 2001). It ranges from zero (highest diversity) to one (monotony); thus an index value of one indicates coverage by a single kind of substrate. Since much of the data on physical and biological parameters may not meet the criteria for normality and homogeneity of variances, parametric one-way ANOVA or non-parametric Kruskall-Wallis tests (Kruskall-Wallis) were applied to the data after testing for normality. Study sites were then compared for differences in physical conditions (substrate diversity), fish density, mobility pattern groups and index of diversity $\left(H^{\prime}\right)$ of fish assemblages (Zar 1996).

An additional Student-Neumann-Keuls (SNK) test of multiple-comparisons of means was applied as a post hoc test (Zar 1996). The relationships between diversity indices, species density, and physical parameters were examined using Spearman rank-correlation (Zar 1996). Association between the most abundant species, mobility pattern groups and their relationship with the habitat was examined using canonical correspondence analysis (CCA). The method operates on field data on abundances of species and data for environmental variables at zones and extract from the measured environmental variables synthetic gradients (ordination axes, fit given by weighted variance) that maximize niche separation (given by eigenvalues) (Ter Braak and Verdonschot 1995). Habitat-related differences in size distribution were examined for all species based on length frequencies and applying chi-square analysis to the size groups. Fish abundances for different zones were pooled and presented in a rank-order of species according to their corresponding log numbers in order to easily visualise species richness and the relative importance of live coral coverage and low coral coverage substrates versus complexity (zone number) at the different study zones (Log series model) (Wolff and Alarcón 1993).

\section{Results}

Substrate diversity

One-way ANOVA (Table 2) reveals significant differences between some zones with respect to Simpson's diversity index. It is close to zero (highest substrate diversity) for all shallow rocky zones that are more exposed to waves $(7,9,10)$, for one of the complex deep rocky zones (8) and for the massive coral reefs (5, $6)$. It is close to one (monotony) for the rubble $(1,2)$, the deep sandy rocky zone (3), deep rocky walls (4) and pocilloporid branching coral reefs $(11,12)$. 
Table 2 Results of parametric (one-way ANOVA: $F$, MS) and non-parametric (Kruskal Wallis, $H$ ) ANOVA and multiple comparisons (SNK) for comparing diversity (fish and habitat) and mobility groups (categories) between study zones in Bahía Honda

\begin{tabular}{|c|c|c|c|c|c|c|}
\hline & $H$ & $d f$ & $F$ & MS & $P$ & Multiple comparisons (SNK) \\
\hline Substrate diversity (Simpson index) & 31.26 & 11 & NND & NND & 0.001 & Other zones $<1=2=3=4=11=12$ \\
\hline Fish diversity $\left(H^{\prime}\right)$ & ND & 11 & 11.76 & 0.101 & 0.001 & Other zones $>1=2=11=12$ \\
\hline Fish abundance & 23.61 & 11 & NND & NND & 0.014 & Other zones $>1=2=3=4=5=6$ \\
\hline Category 1 & 31.77 & 11 & NND & NND & 0.001 & Other zones $>1=3=6$ \\
\hline Category 2 & 21.86 & 11 & NND & NND & 0.02 & Other zones $>7=9$ \\
\hline Category 3 & 39.76 & 11 & NND & NND & 0.001 & Other zones $<4=7=9=10$ \\
\hline
\end{tabular}

$N D$ Normal distribution of data, $N N D$ no normal distribution of data

Taxonomic structure of the fish community and its relationship with habitat

One hundred and twenty-six species of fish belonging to 44 families were found. The total species number increased from rubble over branching coral reef, massive corals, and deep rocky zones to shallow rocky zones with the highest species richness. The number of genera and species differed between all locations, with the greatest difference between shallow and deeper zones; $71 \%$ of the genera were restricted to certain zones, while $18 \%$ of the species occurred in all zones.

Thirty species were abundant enough to allow for a size frequency analysis, and 14 of them showed a significant size-segregation between zones (Fig. 2). Nonterritorial species such as Canthigaster punctatissima, Chromis atrilobata, Epinephelus labriformis, Halichoeres dispilus, Holacanthus passer, Johnrandallia nigrirostris, Scarus ghobban and Thalassoma lucasanum had smaller sizes (juveniles and pre-adults) in shallow high-complexity zones such as pocilloporid reefs (11, $12)$ and shallow rocky reefs $(7,9,10)$; while the number of larger individuals increase in different deeper habitats of intermediate and high complexity (rubble, massive corals and deep rocky zones). Territorial species such as Stegastes acapulcoensis, Stegastes flavilatus and Abudefduf troschellii showed a pattern similar to the non-territorial species mentioned above. Apogon dovii showed an opposite pattern with smaller sizes over deep rocky reefs and massive corals, and larger sizes over shallow branching corals and rocky reefs. Lutjanus argentiventris had smaller sizes at zones of massive corals, while the larger sizes were found in all rocky zones at different depths and different levels of complexity. Larger individuals of Coryphopterus urospilus were mostly found in complex deep rocky zones.

Pomacentrids, labrids, haemulids and apogonids were the most abundant families, the pomacentrid C. atrilobata and the labrid $T$. lucasanum being the most common and abundant species. Chromis atrilobata was present in most shallow wave exposed zones and even in oceanic-current exposed deep zones (8). Thalassoma lucasanum was abundant in most shallow zones while Halichoeres dispilus was common on hard and sandy substrates such as massive-coral reefs and deeper rocky sandy zones. Haemulids were dominant in most shallow zones, while apogonids dominated in crevices on deep rocky walls (Table 3, Fig. 3).

Species associations as related to habitat attributes

The results of the CCA (species codes in Table 3, data in Table 4, and species associations in Fig. 4) show that

Table 3 Dominant species; trophic groups: $\mathrm{O}=$ omnivore; $\mathrm{C}=$ carnivore; $\mathrm{P}=$ piscivore; $\mathrm{MI}=$ mobile-invertebrate feeder; $\mathrm{SI}=$ sessile-invertebrate feeder; $\mathrm{PL}=$ planktivore $; \mathrm{RH}=$ roving herbivore; $\mathrm{TH}=$ territorial herbivore

\begin{tabular}{llll}
\hline Code & Species & Family & $\begin{array}{l}\text { Trophic } \\
\text { group }\end{array}$ \\
\hline ATRO & Abudefduf troschelii & Pomacentridae & O \\
AHAN & Acanthemblemaria hancocki & Chaenopsidae & MI \\
ADOV & Apogon dovii & Apogonidae & PL \\
APAC & Apogon pacificus & Apogonidae & PL \\
BDIP & Bodianus diplotaenia & Labridae & MI \\
CPUN & Canthigaster punctatissima & Tetraodontidae & O \\
CCAB & Caranx caballus & Carangidae & P \\
CATR & Chromis atrilobata & Pomacentridae & PL \\
COXY & Cirrhitichthys oxycephalus & Cirrhitidae & MI \\
CURO & Coryphopterus urospilus & Gobiidae & MI \\
EPUN & Elacatinus punticulatus & Gobiidae & SI \\
HMAC & Haemulon maculicauda & Haemulidae & C \\
HSTE & Haemulon steindachneri & Haemulidae & C \\
HSCU & Haemulon scudderi & Haemulidae & C \\
HDIS & Halichoeres dispilus & Labridae & MI \\
HMEL & Halichoeres melanotis & Labridae & MI \\
JNIG & Johnrandallia nigrirostris & Chaetodontidae & O \\
LARG & Lutjanus argentiventris & Lutjanidae & C \\
PCOL & Paranthias colonus & Serranidae & PL \\
PLAT & Prionurus laticlavius & Acanthuridae & RH \\
SGHO & Scarus ghobban & Scaridae & RH \\
SPSI & Serranus psittacinus & Serranidae & C \\
SACA & Stegastes acapulcoensis & Pomacentridae & TH \\
SFLA & Stegastes flavilatus & Pomacentridae & TH \\
TLUC & Thalassoma lucasanum & Labridae & PL \\
\hline & & &
\end{tabular}



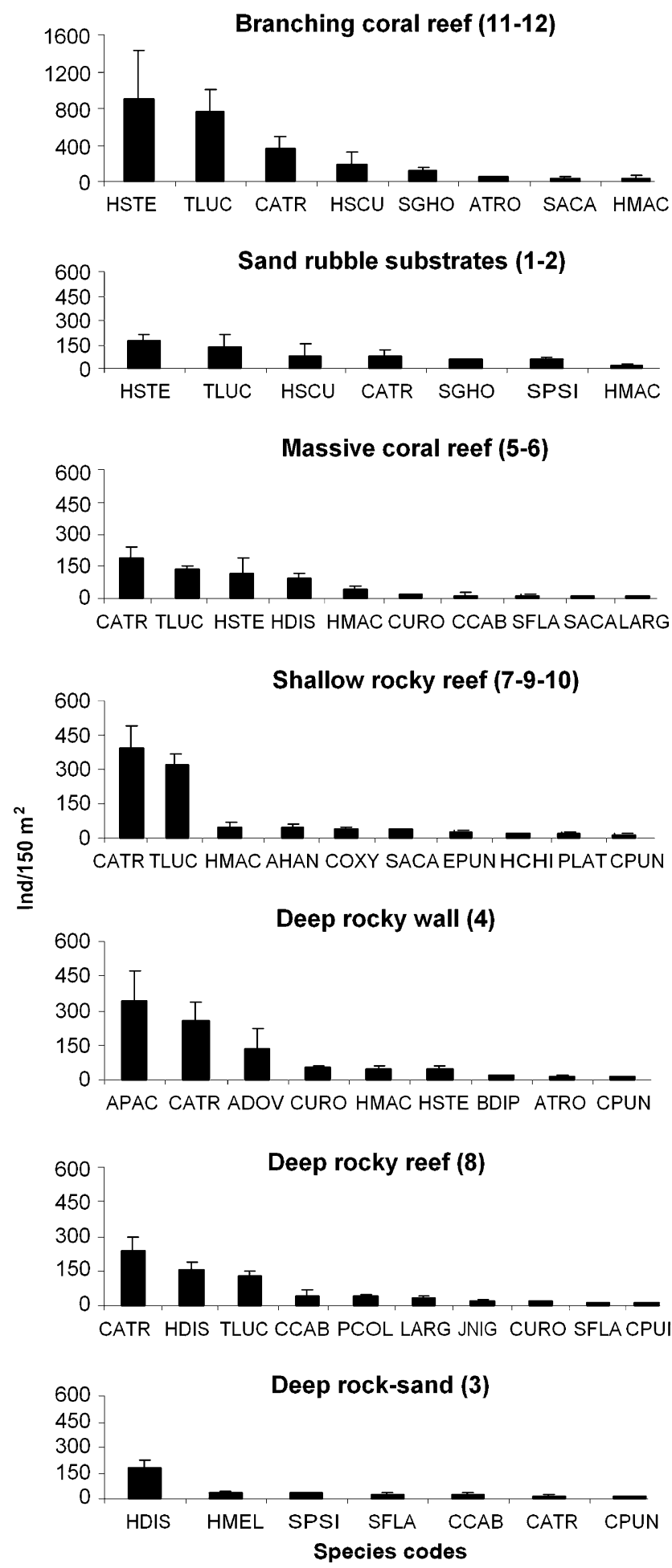

Fig. 3 Density (individuals $/ 150 \mathrm{~m}^{2}{ }^{2} \mathrm{SE}$ ) for the most abundant species on different habitats found in Bahia Honda, Panama (for species codes, see Table 3)

fishes related to shallow branching corals and sandrubble (negative side of axis 2; 1, 2, 11, 12; HSCU, HSTE and SGHO). The negative part of Axis 1 shows species in shallow rocky wave exposed zones $(7,9$ and
10; AHAN, CCAB, COXY, EPUN, PLAT and SACA). There is a depth gradient in the other two rocky-sandy deeper zones with its particular species (3, 8; SFLA, HDIS, HMEL, JNIG, LARG and PCOL). The rock wall zone (4) characterised by sponges and rock-encrusting red algae has another particular group of fish species (APAC, ADOV, BDIP and CURO). A fourth group is comprised by species found in most (mainly shallow) study zones (ATRO, CATR, TLUC, SPSI, HMAC and CPUN).

Fish diversity and abundance

The results of parametric one-way ANOVA and multiple comparisons (SNK) for fish diversity show significant differences between zones. In general, fish diversity was higher in most rocky zones and zones of massive corals, and lower above branching coral reefs $(11,12)$ and rubble $(1,2)$.

These differences can be appreciated in more detail in the log-series model in Fig. 5. The line is flatter (greatest evenness) and its intersection with the axis (species richness) is greater in the complex rocky zones (7-10) and in the massive coral reef $(5,6)$, independent of their coral coverage or depth. All these zones have a more diverse benthic component (lower Simpson index). The rubble, branching corals and sand zones have higher slopes and lower regression coefficients, indicating a higher dominance within the assemblage and a less diverse community, respectively. All outlier points above the lines (omitted in Fig. 5 for better graphic visualization) represent the dominant species of pomacentrids and labrids. More species were found in areas with complex massive coral and complex rocky reef. The non-parametric ANOVA shows that fish abundance differs significantly between zones; zones of highest complexity (particularly shallow rocky zones and branching corals, 7-12) have higher fish abundances, specially a high number of juveniles of different species.

\section{Summary of correlations}

The Spearman rank-correlation analysis (Fig. 6) shows a significant positive correlation between species-richness/index of diversity and the average size of holes (along with their variation in size). The correlation was strongest for most of the substrates from rocky reefs, and was also positive for live massive corals. Our results show that surface complexity is only positively correlated with species richness and that substrate monotony (Simpson index, value close to 1 ) is related to a less diverse fish community. In- 
Table 4 Canonical correspondance analysis

\begin{tabular}{lrrrrrrrrr}
\hline \multicolumn{1}{l}{ Species association (Fig. 4) } & & & Mobility groups (Fig. 7) \\
\hline VCP & 32.17 & 52.12 & 69.78 & 80.39 & 86.12 & 90.92 & 94.39 & 69.85 \\
SEV & 0.48 & 0.29 & 0.26 & 0.15 & 0.08 & 0.07 & 0.05 & 0.18 & 0.07 \\
\hline
\end{tabular}

$V C P$ Variance in cumulative percentage, $S E V$ Sums of eigenvalues

verse correlations were also found in richness and diversity with dead and living branching coral, and with rubble.

Fish abundance (individuals/census) seems to be positively correlated with complex substrates such as branching corals reef and shallow rocky reef. This is due to the high abundance of pomacentrids and labrids (especially juveniles) in these habitats. Total fish abundance was inversely correlated with all substrates related to rubble zones (Fig. 6).
Fig. 4 Canonical correspondence analysis $(C C A)$ for fish abundance versus substrate coverage and environmental variables (codes for substrate categories in Table 1 , for species in Table 3)

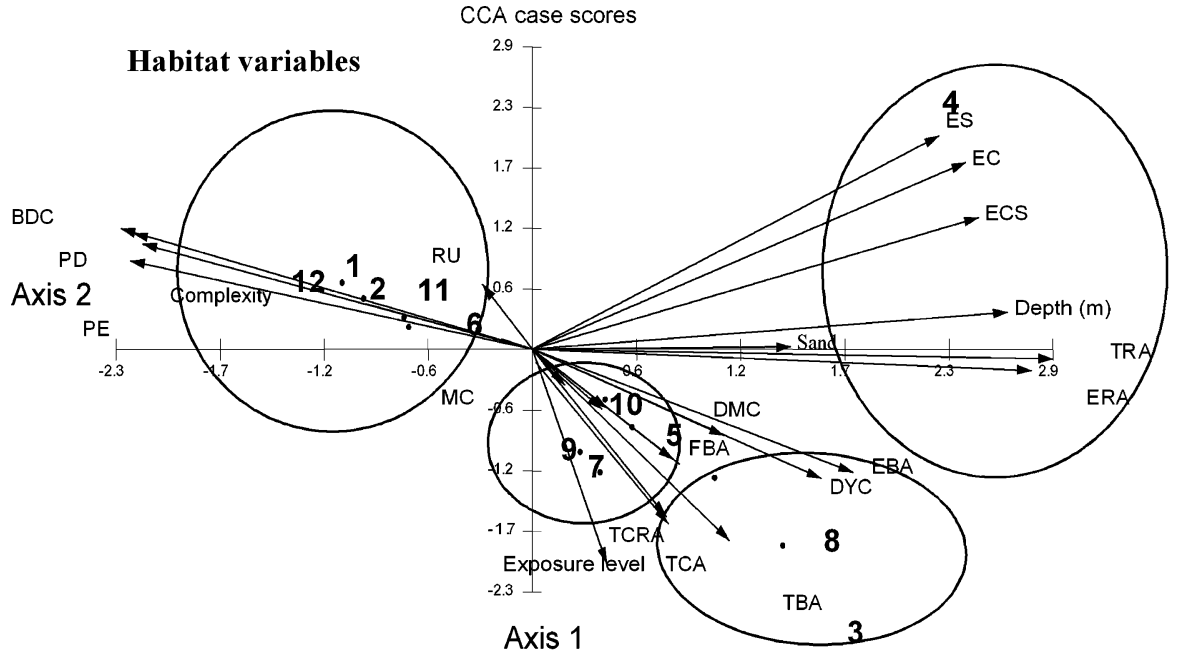

Species composition

Deep rock walls

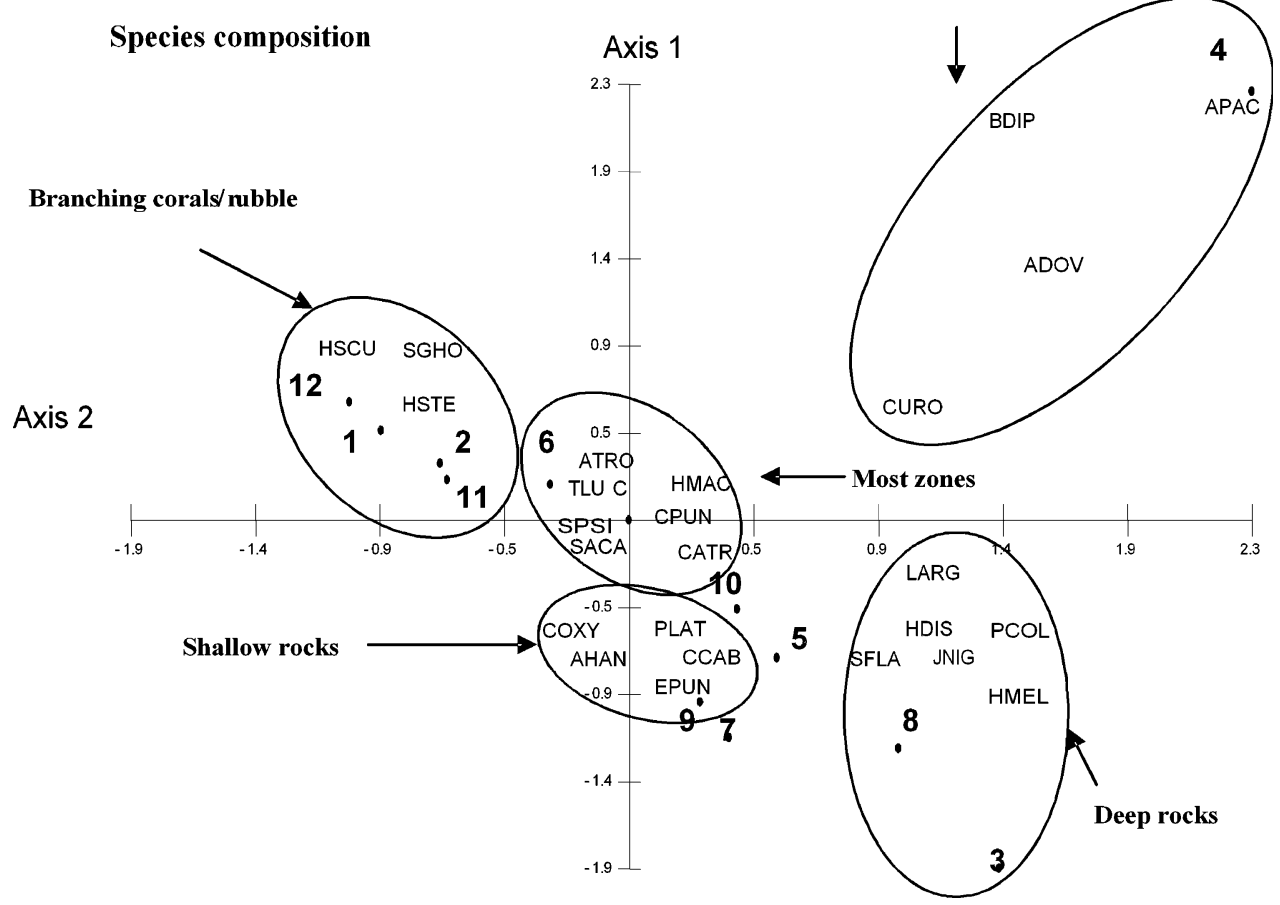


Mobility and home-range

Most of the shallow wave-exposed zones $(7,9,10)$ and the deep zone (8) with strongest exposure to oceanic currents have fishes with high horizontal and vertical mobility (Category 1). The exceptions were for one of the rubble zones (1), the deep rock sand zone (3), and a massive coral reef zone (6). All these zones were closer to the mainland and less exposed to currents and waves. Relatively sedentary species (Category 2) were abundant in most zones except in two rocky shallow zones strongly exposed to waves. Site-attached species (Category 3) were more represented in zones with lower proportion of sand and higher coverage of hard rocky substrate: In shallow rocky zones $(7,9,10)$, and on rocky walls (4). This correlation of mobility groups with certain habitat attributes and zones is revealed by the CCA-Analysis (12 zones; all species included, results data in Table 4, associations of categories in Fig. 7). This analysis shows a gradient of exposure (zones 7, 9 and 10). Fishes in Category 3 (site-attached species) are represented by small chaenopsids (e.g. Acanthemblemaria hancockii) on small holes in basaltic rocks. In the coral reef deeper sandy zones, fishes of Category 2 (relative sedentary species) are more abundant. Category 1 (fishes of high horizontal and vertical mobility) are more related to rocky reefs.

\section{Trophic groups}

Planktivores account for more than $50 \%$ of the relative abundance in most zones, and a similar pattern is followed by carnivores with $30 \%$, mobile invertebrate feeders with $20 \%$, piscivores with $20 \%$, and herbivores and sessile invertebrate feeders with a low relative abundance of $10 \%$. Planktivores have relatively low species numbers compared to other trophic groups: Carnivores account for $32 \%$, mobile invertebrate feeders for $23 \%$, and omnivores for $13 \%$ of the species in BH-GCH. In general, the number of species within trophic groups increases towards rocky and massive coral zones (Fig. 8).

\section{Discussion}

Distribution patterns as related to water depth

In $\mathrm{BH}-\mathrm{GCH} 71.4 \%$ of the species found have smaller sizes and higher densities in shallow high complex habitats, while larger size classes are mainly associated with complex deep zones with bigger crevices. Small individuals thus hide in between coral branches, com- plex rocky-reef and small holes in shallow areas, probably as an effective way to avoid the predation encountered in deeper zones (Almany 2004a, b). According to Fulton and Bellwood (2002) this shift in microhabitat use could also largely be due to flow-refuging behaviour, where substrate complexity and boundary layer act as refuges from water flow. Some of the species associations observed in the center of the CCA ordination diagram represent the better swimmers such as the genera Thalassoma and Chromis, indicative for habitats of stronger currents and greater water movement (Floeter et al. 2004) (see also further discussion below). The distribution of the two territorial herbivores $S$. acapulcoensis and $S$ flavilatus differ by depth (Dominici-Arosemena et al. 2005; Arburto-Oropeza and Balart 2001; this study). This example confirms that substratum selection alone is insufficient to explain the discrete spatial distribution of adults. Possibly, habitat selection and interspecific aggression combine to determine the adult distribution of these species of Stegastes (Bay et al. 2001). Our correspondence analysis suggests many subdivisions and well-composed groups of species in rocky zones, where assemblages vary along a depth gradient, either due to differential food requirements or due to particular habitat adaptations (e.g. oceanic planktivores with higher swimming capacity in shallow zones vs. less mobile species on soft bottom environments in deeper zones).

Species richness, diversity patterns, spatial variation and relationship with habitat variables

As shown in our log series model (Fig. 5), aspects of habitats other than live coral cover-richness are involved in the maintenance of diversity in this region. Massive coral zones (5 and 6) show lower fish abundance than, but similar fish species richness as most rocky zones with high substrate diversity. Reef fish may thus well be characteristic of-but not restricted to-coral reefs as has already been stated by other authors (Robertson 1998; Bellwood 1998). Species richness correlates negatively with monotony (less diverse substrate) and positively with hole variables (numbers, variation and size), similarly as has been described for rocky shores in higher latitudes (Ferreira et al. 2001; García-Charton and Pérez-Ruzafa 2001) and in the Red Sea (Khalaf and Kochzius 2002). As indicated by our research in $\mathrm{BH}-\mathrm{GCH}$, and confirmed by other studies, coral cover alone has little influence on the species richness and abundance of fish (Roberts and Ormond 1987; Luckhurst and Luckhurst 1978), and coral reef community structure (in general and fish community in particular) seems to be a complex, 
Fig. 5 Species rank versus log-abundances (Log-series model); zone numbers in bold

Living corals / no rocks

$\mathbf{Y}=\mathbf{a}-\mathbf{b} \mathbf{x}$

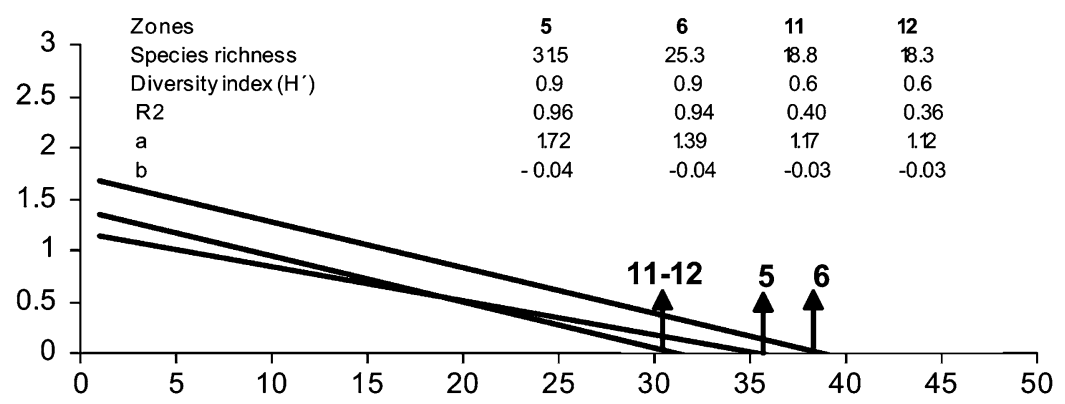

Shallow corals / rocks

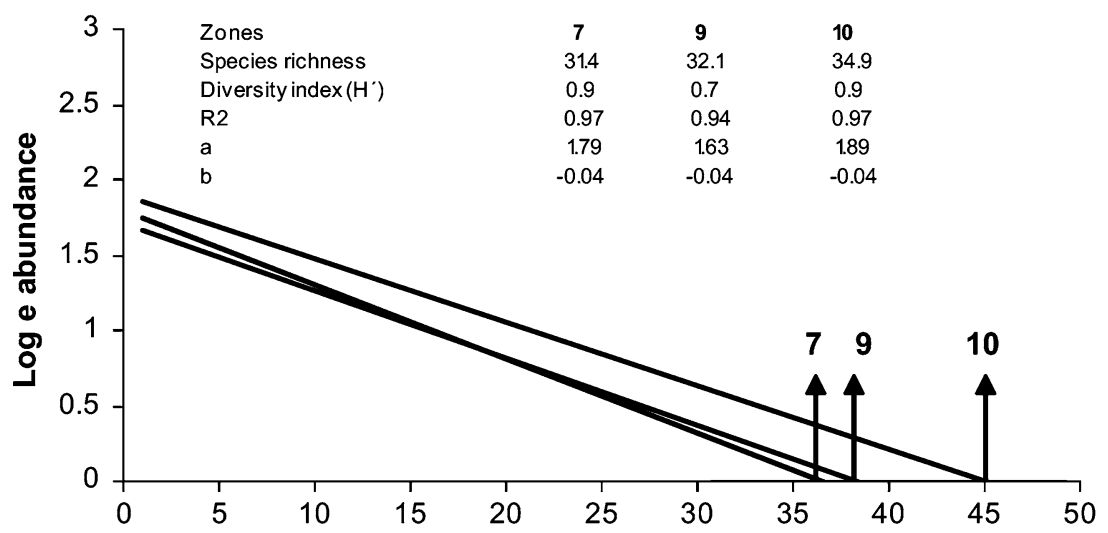

\section{Low coral zones}

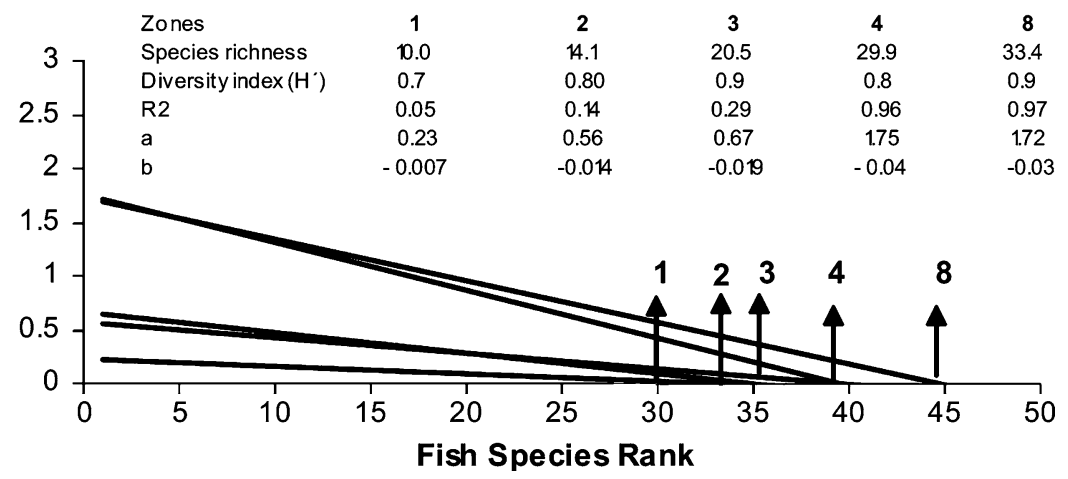

indirect and non-linear consequence of reef structure and environmental conditions (Bradbury and Young 1981).

Mobility, home range and local patterns of trophic groups

Better swimmers (Category 1) such as Thalassoma sp. are adapted to, and have high densities in exposed upper shallow rocky zones (7, 9 and 10), in shallow pocilloporid reef subjected to intermittent currents due to tide variation (11 and 12), and in the oceanic deep zone most exposed to Currents (8), while mid slope zones are characterized by less efficient swimmers (Category 2) such as the genus Halichoeres (Bellwood and Wainwrigt 2001). These patterns are similar among geographical regions (Bellwood et al. 2002). In BHGCH, small site-attached cirhitids in branching corals (P. elegans) over shallow rocks, and chaenopsids (Category 3) in holes of basaltic rock may better withstand strong waves and currents. Most studies regarding these mobility guilds have been focused on labrids (Bellwood and Wainwright 2001; Bellwood et al. 2002), acanthurids and pomacentrids (Fulton et al. 2005), and further research on these patterns is needed in other reef fish families. The distribution of 
Fig. 6 Spearman rank correlations, fish community and habitat variables; $n=288$, $\#=<0.0001$ (substrate codes in Table 1)
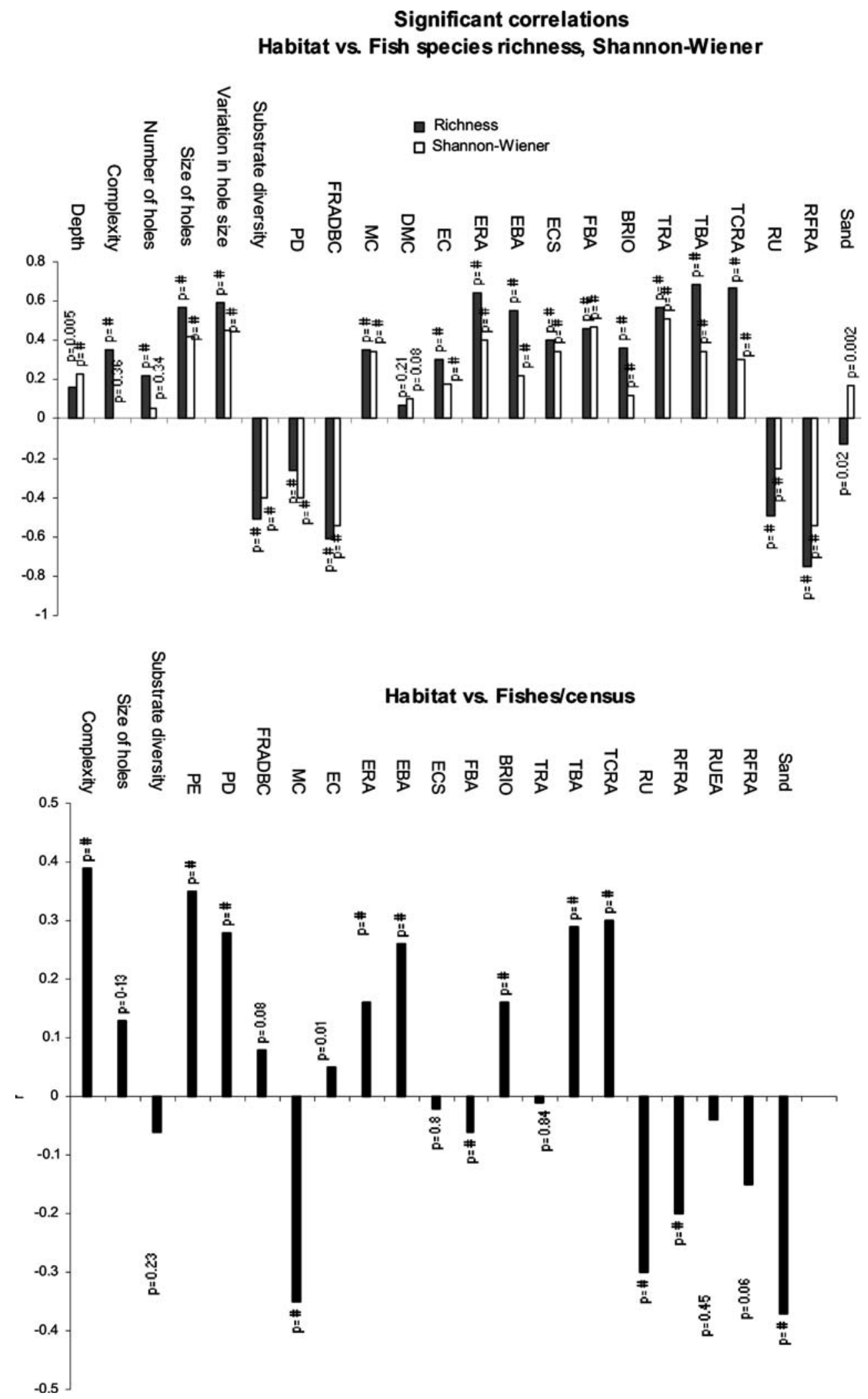

these mobility groups in BH-GCH may be related to tides and currents, with the good swimmers (Category 1) being more homogenously distributed but with a higher affinity to shallow-rocky-branching coral and deeper zones that are more affected by oceanic currents. Good swimmers are able to withstand strong 
Fig. 7 Canonical

correspondance analysis; mobility groups (categories) versus percentage of substrate coverage and environmental variables associated with the respective zones (zone numbers in bold, substrate codes in Table 1)

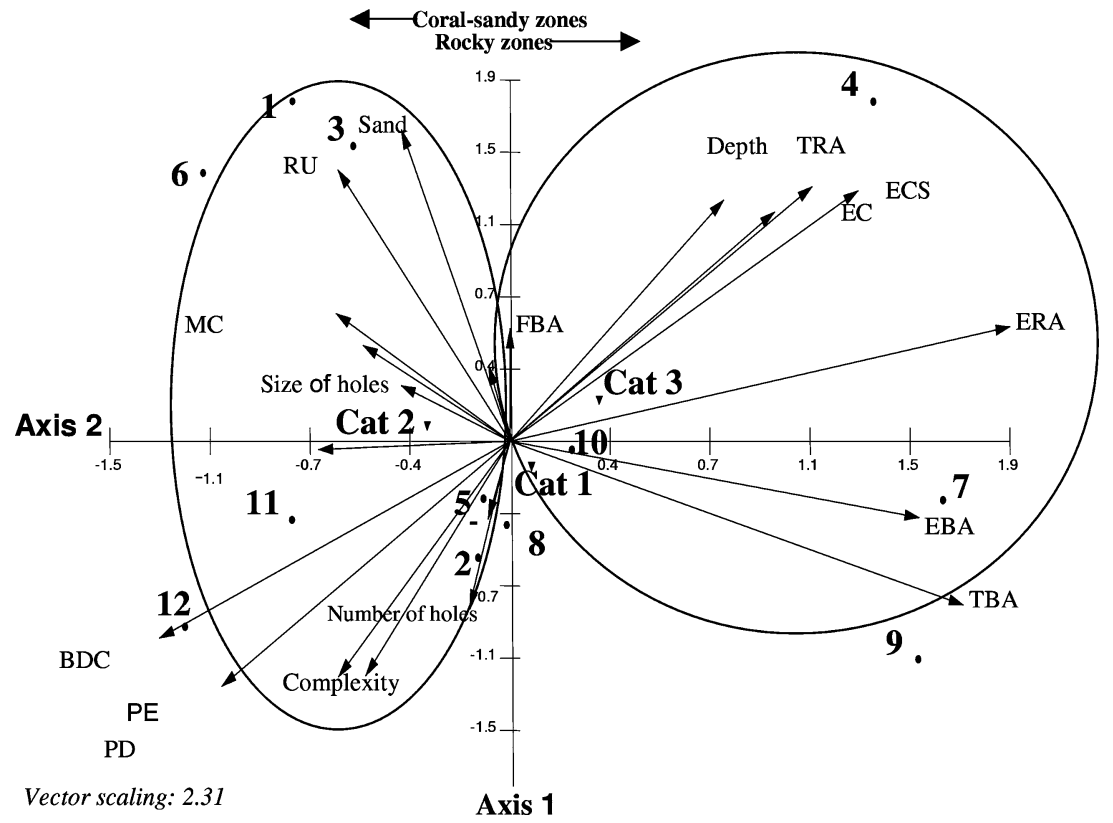

currents and most of them feed on oceanic plankton. As shown in this study, this pattern varies among sites, with a decreasing abundance of category 1 fish in zones close to the mainland where current intensity is lower. Planktivores indeed account for as much as $80 \%$ of all fish in many zones in BH-GCH. Zooplankton reside in a constantly flowing environment, maintaining their depth by swimming against upwelling and downwelling currents. This explains why oceanic fronts become major feeding grounds for planktivores (Genin et al. 2005; Thresher 1983). In BH-GCH roving herbivores are represented by scarids in shallow zones in low frequencies when compared with other trophic groups. Other roving herbivores such as acanthurids seem to prefer certain types of algae common in exposed reef flats such as the zones 7,9 and 10 (Sluka and Miller 2001), where the surgeon fish Prionurus laticlavius was found in incidental aggregations.

The trophic groups that feed on high nutritive food sources (Floeter et al. 2004) such as mobile-invertebrate feeders, carnivores, piscivores and omnivores have a wide spatial distribution and most of them a high relative abundance in BH-GCH: Piscivorous fishes are particularly important here compared to other TEP regions, namely carangids and serranids of large size classes and even top predators such as the great hammerhead sharks Sphyrna mokarran that were seen occasionally (personal observation). Recent studies have pointed to the importance of piscivorous fish as regulators of the abundance of prey species, probably including many small territorial herbivores. This top-down control by piscivores may maintain high species diversity due to decreasing the competition among subordinate species by lowering their population densities (Almany 2004a, b; Beukers-Stewart and Jones 2004). A reduction in the recruitment of many fish families due to environmental stochasticity (i.e. phenomena such as ENSO) may in addition provoke a bottom-up regulatory force in balancing the whole community structure (Almany 2004a, b).

\section{Comparison with other regions in TEP}

In Southern Baja California (SBC) $40 \%$ of the species that feature significant habitat differences between juveniles and adults are the same as in BH-GCH. Some benthic components such as rodoliths and black corals may also provide protection for juveniles (ArburtoOropeza and Balart 2001). Only $39.5 \%$ of the species considered as dominant (e.g. T. lucasanum and C. atrilobata) and common in the SBC are present in $\mathrm{BH}-\mathrm{GCH}$, and both regions share a similar deep water fish assemblage. Chaenopsids, gobids, damselfishes such as $S$. acapulcoensis, carangids and apogonids are less abundant or considered as rare species in SBC (Arburto-Oropeza and Balart 2001). A similar situation holds for the Galapagos with a large number of species of Peruvian-Chilean origin, which were absent in our surveys (Edgar et al. 2004), and with only 50\% of the species shared with BH-GCH. Only $23 \%$ of the species that we found in the $\mathrm{GCH}$ are of Indo-Pacific or circumtropical origin, and many are shared with the other TEP regions mentioned, but these patterns vary among the mainland and offshore islands (Table 5, 6). Geographic history and isolation, environmental conditions (e.g. oceanic currents, ENSO events), duration 


\section{Territorial herbivores}
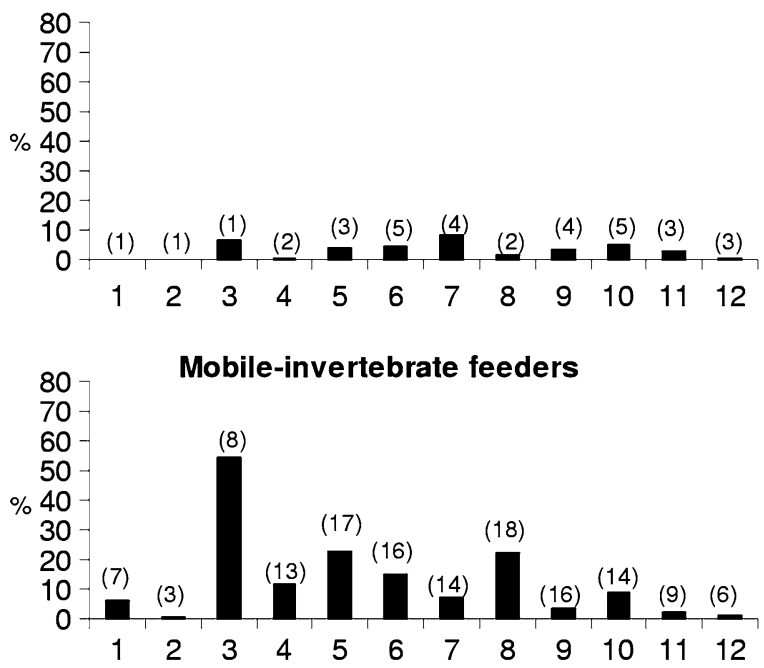

Carnivores

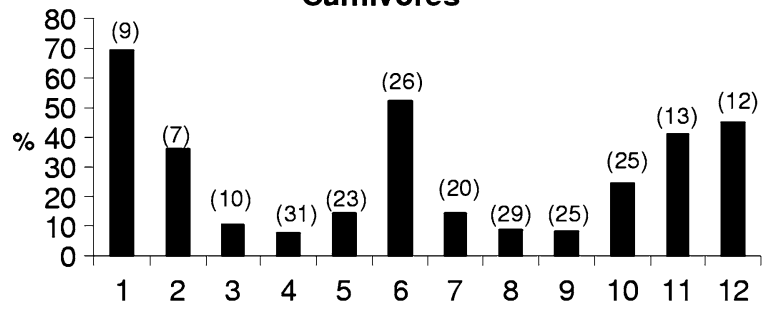

Sessile-invertebrate feeders

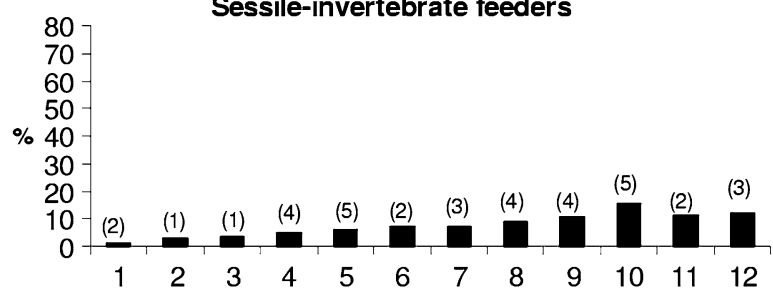

Planktivores

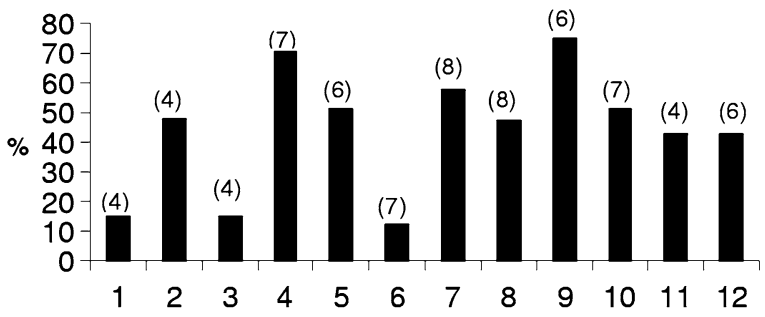

Roving herbivores

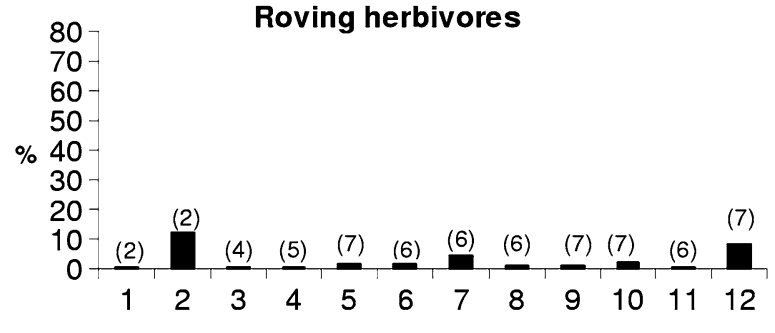

Omnivores

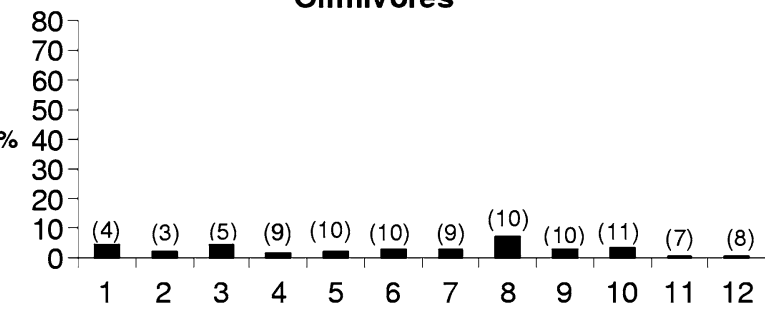

Piscivores

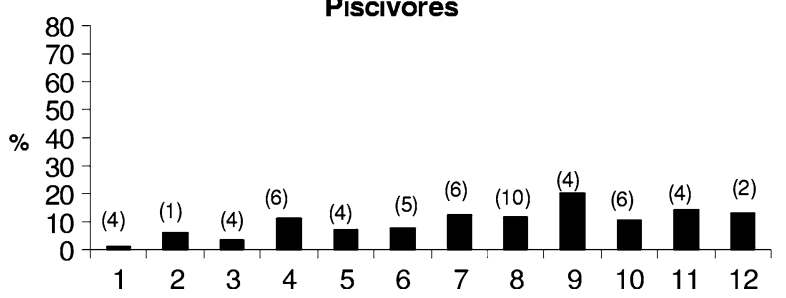

Fig. 8 Frequency $(\%)$ of the principal trophic groups in the different study zones (1-12); numbers in parentheses indicate the number of species in each group

of the pelagic stage of fish larvae, and substrate may play a role in shaping these differences. The species richness in the $\mathrm{GCH}$ is higher than in most other areas in the TEP but slightly lower than at the Galapagos and Clipperton Islands (Allen and Robertson 1997; Edgar et al. 2004). The species composition (even if we exclude species that may be over-fished for human consumption) around near shore islands (e.g. Gorgona) and in other warmer regions close to the mainland is similar, but species numbers and abundance are lower compared to the GCH. This may be due to the more constant conditions (e.g. salinity and temperature) along with the presence of a wider set of habitats and greater availability of shelter at our study site, the largest archipelago in the TEP. The higher species numbers reported for oceanic islands (e.g. Galapagos and Clipperton Islands) which are attributed to the larval inputs from different geographical sources (other islands, continental shores of TEP), has motivated authors to suggest that in this region insular and continental components of fish fauna, subjected to habitat fragmentation, should be treated separately when analysing such patterns (Mora and Robertson 2005).

In terms of trophic groups, it seems that in all TEP regions investigated planktivores and invertebrate feeders dominate, while herbivores are low in numbers (Zapata and Morales 1997; Aburto-Oropeza and Balart 2001; Dominici-Arosemena et al. 2005; this study). The predominance of good swimming planktivores (e.g. C. atrilobata and T. lucasanum) seems to be a common pattern in the whole TEP, but their proportion may vary among regions. The data available shows that their densities increase in regions of higher tide variation: The relative abundance of better swimming 
Table 5 List of species found and their distribution to trophic groups (TG; see Table 3) and study zones (1-12; see Fig. 1)

Family/species

Acanthuridae

Aacanthurus nigricans ${ }^{\mathrm{a}}$

A. xanthopterus

A. triostegus $^{\mathrm{a}}$

Ctenochaetus marginatus

Prionurus laticlavius

Apogonidae

Apogon dovii

Apogon pacificus

Aulostomidae

Aulostomus chinensis ${ }^{\mathrm{a}}$

Balistidae

Balistes polylepis

Pseudobalistes naufragium $^{\mathrm{a}}$

Sufflamen verres

Blenniidae

Ophioblennius steindachneri

Plagiotremus azaleus

Bothidae

Bothus mancus ${ }^{\mathrm{a}}$

Carangidae

Carangoides otrynter

Carangoides caballus

Caranx lugubris ${ }^{\mathrm{b}}$

C. melampygus ${ }^{\mathrm{a}}$

C. sexfasciatus ${ }^{\mathrm{a}}$

Elagatis bipinnulata ${ }^{\mathrm{b}}$

Gnathanodon speciosus

Oligoplites refulgens

Selene peruviana

Seriola rivoliana ${ }^{\mathrm{b}}$

Trachinotus rhodopus

Chaenopsidae

Acanthemblemaria exilispinus

Acanthemblemaria hancocki

Mccoskerichthys sandae

Chaetodotidae

Chaetodon humeralis

Johnrandallia nigrirostris

Cirrhitidae

Cirrhitus rivulatus

Cirrhitichthys oxycephalus ${ }^{\mathrm{a}}$

Dasyatidae

Dasyatis dipterura

Dasyatis longa

Diodontidae

Diodon holocanthus ${ }^{\mathrm{b}}$

Diodon hystrix ${ }^{\mathrm{b}}$

Ephippididae

Chaetodipterus zonatus

Fistulariidae

Fistularia commersonii $^{\text {a }}$

Gerreidae

Eucinostomus currani

Diapterus aureolus

Gobiidae

Elacatinus inornatus

Elacatinus punticulatus

Coryphopterus urospilus

Haemulidae

Anisostremus caesius

TG

1

2

$\mathrm{RH}$

$\mathrm{RH}$

$\mathrm{RH}$

RH

$\mathrm{RH}$

PL

PL

$\mathrm{P}$

$\mathrm{O}$

$\mathrm{O}$

SI

TH

P

MI

$\mathrm{P}$
$\mathrm{P}$
$\mathrm{P}$
$\mathrm{P}$
$\mathrm{P}$
$\mathrm{P}$
$\mathrm{P}$
$\mathrm{P}$
$\mathrm{P}$
$\mathrm{P}$
$\mathrm{P}$

MI

MI

PL

SI

O

$\mathrm{C}$

C

MI

MI

MI

MI

$\mathrm{O}$

C

MI

MI

MI

SI

MI

C

$\mathrm{X}$
$\mathrm{X}$

$\mathrm{X}$

(1)

II

$\mathrm{X}$
$\mathrm{X}$
$\mathrm{X}$

(1)

$\begin{array}{lllllll}6 & 7 & 8 & 9 & 10 & 11 & 12\end{array}$

3 $5+2$

$\mathrm{x}$

$\mathrm{x} \quad \mathrm{x} \quad \mathrm{x}$

$x+x$

$\mathrm{x}$

$\begin{array}{cc}\mathrm{x} & \mathrm{x} \\ \mathrm{x} & \mathrm{x}\end{array}$

$\begin{array}{ccc}x & x & x\end{array}$

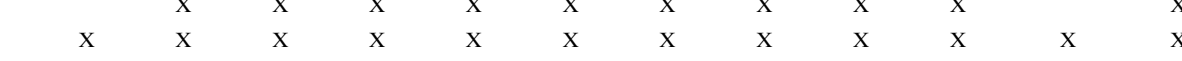

$\begin{array}{lllllllllll}X & x & x & x & x & & x & & x & x & x \\ & x & x & x & x & x & x & x & x & x & x\end{array}$

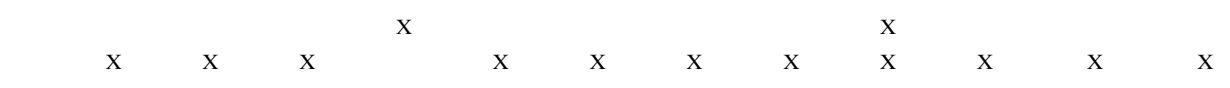

$x-x \quad x$

$\begin{array}{llll}x & x & & \\ x & x & \end{array}$

(n)

\begin{tabular}{|c|c|c|c|c|c|}
\hline & & & X & & \\
\hline$x$ & $x$ & $x$ & $\mathrm{X}$ & $x$ & $\mathrm{X}$ \\
\hline
\end{tabular}

$\mathrm{x}$

$\mathrm{x}$

\begin{tabular}{|c|c|c|c|c|c|c|c|c|c|c|}
\hline & & $\mathrm{X}$ & & & & $\mathrm{X}$ & & & & \\
\hline & & $x$ & $x$ & & $\mathrm{X}$ & $\mathrm{X}$ & $\mathrm{X}$ & $\mathrm{X}$ & & \\
\hline $\mathrm{x}$ & $x$ & $\mathrm{X}$ & $x$ & $x$ & $\mathrm{X}$ & $\mathrm{X}$ & $x$ & $x$ & $X$ & $x$ \\
\hline & & & & $x$ & & & & & & \\
\hline
\end{tabular}


Table 5 continued

\begin{tabular}{|c|c|c|c|c|c|c|c|c|c|c|c|c|c|}
\hline Family/species & TG & 1 & 2 & 3 & 4 & 5 & 6 & 7 & 8 & 9 & 10 & 11 & 12 \\
\hline A. interruptus & $\mathrm{C}$ & & & & & & $\mathrm{x}$ & & & & & & \\
\hline A. taeniatus & $\mathrm{C}$ & & & & $\mathrm{x}$ & $\mathrm{x}$ & $\mathrm{x}$ & & $\mathrm{x}$ & & & & \\
\hline Haemulon flaviguttatum & $\mathrm{C}$ & & & & $\mathrm{x}$ & & $\mathrm{x}$ & & $\mathrm{x}$ & & $\mathrm{x}$ & & \\
\hline H. maculicauda & $\mathrm{C}$ & & & & $\mathrm{x}$ & $\mathrm{x}$ & $\mathrm{x}$ & & & & $\mathrm{x}$ & & \\
\hline H. scudderi & $\mathrm{C}$ & $\mathrm{x}$ & & & & & & & & & $\mathrm{x}$ & $\mathrm{x}$ & $\mathrm{x}$ \\
\hline H. sexfasciatum & $\mathrm{C}$ & & & & & $\mathrm{x}$ & $\mathrm{x}$ & & & & & & \\
\hline H. steindachneri ${ }^{\mathrm{c}}$ & $\mathrm{C}$ & $\mathrm{X}$ & & & & $\mathrm{x}$ & $\mathrm{x}$ & & $\mathrm{x}$ & & $\mathrm{x}$ & $\mathrm{x}$ & $\mathrm{x}$ \\
\hline \multicolumn{14}{|l|}{ Holocentridae } \\
\hline Myripristis berndti $^{\mathrm{a}}$ & PL & & & & & & & & & & $\mathrm{x}$ & & $\mathrm{x}$ \\
\hline M. leiognathus & PL & & & & $\mathrm{x}$ & $\mathrm{x}$ & & $\mathrm{x}$ & $\mathrm{x}$ & $\mathrm{x}$ & & & $\mathrm{x}$ \\
\hline $\begin{array}{l}\text { Sargocentron suborbitalis } \\
\text { Kyphosidae }\end{array}$ & PL & & & & & $\mathrm{x}$ & $\mathrm{x}$ & $\mathrm{x}$ & & & $\mathrm{x}$ & & $\mathrm{x}$ \\
\hline Kyphosus elegans & $\mathrm{O}$ & & & $\mathrm{X}$ & & $\mathrm{X}$ & $\mathrm{x}$ & $\mathrm{x}$ & $\mathrm{x}$ & $\mathrm{x}$ & $\mathrm{x}$ & & \\
\hline Sectator ocyurus & MI & & & & $\mathrm{x}$ & & & & $\mathrm{x}$ & & & & \\
\hline \multicolumn{14}{|l|}{ Labridae } \\
\hline Bodianus diplotaenia & MI & & & $\mathrm{x}$ & $\mathrm{x}$ & $\mathrm{x}$ & $\mathrm{x}$ & $\mathrm{x}$ & $\mathrm{x}$ & $\mathrm{x}$ & $\mathrm{x}$ & $\mathrm{x}$ & $\mathrm{x}$ \\
\hline Halichoeres chierchiae & MI & & & $\mathrm{x}$ & $\mathrm{x}$ & $\mathrm{x}$ & $\mathrm{x}$ & $\mathrm{x}$ & $\mathrm{x}$ & $\mathrm{x}$ & $\mathrm{x}$ & $\mathrm{x}$ & \\
\hline H. dispilus & MI & $\mathrm{x}$ & $\mathrm{x}$ & $\mathrm{x}$ & $\mathrm{x}$ & $\mathrm{x}$ & $\mathrm{x}$ & $\mathrm{x}$ & $\mathrm{x}$ & $\mathrm{x}$ & $\mathrm{x}$ & $\mathrm{x}$ & \\
\hline H. melanotis & MI & $\mathrm{x}$ & & $\mathrm{x}$ & $\mathrm{x}$ & $\mathrm{x}$ & & $\mathrm{x}$ & $\mathrm{x}$ & & $\mathrm{x}$ & & \\
\hline H. nicholsi & MI & & $\mathrm{x}$ & $\mathrm{x}$ & $\mathrm{x}$ & $\mathrm{x}$ & $\mathrm{x}$ & $\mathrm{x}$ & $\mathrm{x}$ & $\mathrm{x}$ & $\mathrm{x}$ & $\mathrm{x}$ & \\
\hline H. notospilus & MI & & & & $\mathrm{x}$ & $\mathrm{x}$ & $\mathrm{x}$ & & & & $\mathrm{x}$ & $\mathrm{x}$ & \\
\hline Novaculichthys taeniourus ${ }^{\mathrm{a}}$ & MI & & & $\mathrm{x}$ & & $\mathrm{x}$ & & $\mathrm{x}$ & $\mathrm{x}$ & $\mathrm{x}$ & $\mathrm{x}$ & & \\
\hline Thalassoma lucasanum & PL & $\mathrm{x}$ & $\mathrm{x}$ & $\mathrm{x}$ & $\mathrm{x}$ & $\mathrm{x}$ & $\mathrm{x}$ & $\mathrm{x}$ & $\mathrm{x}$ & $\mathrm{x}$ & $\mathrm{x}$ & $\mathrm{x}$ & $\mathrm{x}$ \\
\hline T. grammaticum & MI & & & & & & & & & & & $\mathrm{x}$ & \\
\hline Iniistius pavo ${ }^{\mathrm{a}}$ & MI & & & $\mathrm{x}$ & & & & & & & & & \\
\hline \multicolumn{14}{|l|}{ Labrisomidae } \\
\hline Malacoctenus ebisui & MI & & & & & & $\mathrm{x}$ & $\mathrm{x}$ & $\mathrm{x}$ & $\mathrm{x}$ & $\mathrm{x}$ & & \\
\hline Malacoctenus margaritae & MI & & & & & & & & & & $\mathrm{x}$ & & \\
\hline \multicolumn{14}{|l|}{ Lutjanidae } \\
\hline Hoplopagrus guentherii & $\mathrm{C}$ & & & & & & & & & & & & $\mathrm{x}$ \\
\hline Lutjanus argentiventris & $\mathrm{C}$ & & & $\mathrm{x}$ & $\mathrm{x}$ & $\mathrm{x}$ & $\mathrm{x}$ & $\mathrm{X}$ & $\mathrm{x}$ & $\mathrm{x}$ & $\mathrm{x}$ & $\mathrm{x}$ & \\
\hline L. colorado & $\mathrm{C}$ & & & & & & & & $\mathrm{x}$ & & & & \\
\hline L. guttatus & $\mathrm{C}$ & $\mathrm{x}$ & & & & & $\mathrm{x}$ & & & & & & \\
\hline L. inermis & $\mathrm{C}$ & & & & $\mathrm{x}$ & $\mathrm{x}$ & $\mathrm{x}$ & & & & $\mathrm{x}$ & & \\
\hline L. jordani & $\mathrm{C}$ & & & & & $\mathrm{x}$ & & & & & & & \\
\hline L. novemfasciatus & $\mathrm{C}$ & & & & & $\mathrm{x}$ & $\mathrm{x}$ & & & & & & \\
\hline L. viridis & $\mathrm{C}$ & & & & & & & & & & & & $\mathrm{x}$ \\
\hline \multicolumn{14}{|l|}{ Malacanthidae } \\
\hline Malacanthus brevirostris ${ }^{\mathrm{a}}$ & $\mathrm{C}$ & & & $\mathrm{X}$ & $\mathrm{x}$ & & & & $\mathrm{x}$ & & & & \\
\hline \multicolumn{14}{|l|}{ Monacanthidae } \\
\hline Aluterus scriptus ${ }^{\mathrm{b}}$ & $\mathrm{O}$ & & & & & & & & & $\mathrm{x}$ & & & \\
\hline \multicolumn{14}{|l|}{ Mugilidae } \\
\hline Mugil hospes & PL & & & & & & $\mathrm{x}$ & & & & & & \\
\hline \multicolumn{14}{|l|}{ Mullidae } \\
\hline Mulloidichthys dentatus & $\mathrm{C}$ & & & $\mathrm{x}$ & $\mathrm{x}$ & $\mathrm{x}$ & $\mathrm{x}$ & & & & $\mathrm{x}$ & & \\
\hline \multicolumn{14}{|l|}{ Muraenidae } \\
\hline Echidna nebulosa ${ }^{\mathrm{a}}$ & $\mathrm{C}$ & & & & & $\mathrm{x}$ & & $\mathrm{x}$ & $\mathrm{x}$ & $\mathrm{x}$ & $\mathrm{x}$ & $\mathrm{x}$ & \\
\hline Enchelycore octaviana & $\mathrm{C}$ & & & & & & & & $\mathrm{x}$ & & & & \\
\hline Gymnomuraena zebra ${ }^{\mathrm{a}}$ & $\mathrm{C}$ & & & & & & & $\mathrm{x}$ & & $\mathrm{x}$ & & & \\
\hline Gymnothorax castaneus & $\mathrm{C}$ & & & $\mathrm{x}$ & $\mathrm{x}$ & & $\mathrm{x}$ & & $\mathrm{x}$ & $\mathrm{x}$ & $\mathrm{x}$ & $\mathrm{x}$ & $\mathrm{x}$ \\
\hline Gymnothorax flavimarginatus $^{\mathrm{a}}$ & $\mathrm{C}$ & & & & & & & & & & & $\mathrm{x}$ & \\
\hline Muraena lentiginosa & $\mathrm{C}$ & & & $\mathrm{x}$ & $\mathrm{x}$ & & & $\mathrm{x}$ & $\mathrm{x}$ & $\mathrm{x}$ & & $\mathrm{x}$ & \\
\hline \multicolumn{14}{|l|}{ Narcidinidae } \\
\hline Diplobatis ommata & MI & & & & & & & & $\mathrm{x}$ & & & & \\
\hline \multicolumn{14}{|l|}{ Opistognathidae } \\
\hline Opistognathus panamensis & PL & & & & & & & & $\mathrm{x}$ & & & & \\
\hline Ophichthidae & & & & & & & & & & & & & \\
\hline Myrichthys tigrinus & MI & & & $\mathrm{X}$ & & & & & & & & $\mathrm{x}$ & \\
\hline Ostraciidae & & & & & & & & & & & & & \\
\hline Ostracion meleagris $^{\mathrm{a}}$ & SI & & & & & $\mathrm{x}$ & & & & $\mathrm{x}$ & & & \\
\hline Pomacanthidae & & & & & & & & & & & & & \\
\hline Holocanthus passer & $\mathrm{O}$ & & $\mathrm{x}$ & $\mathrm{x}$ & $\mathrm{x}$ & $\mathrm{x}$ & $\mathrm{x}$ & $\mathrm{x}$ & $\mathrm{x}$ & $\mathrm{x}$ & $\mathrm{x}$ & $\mathrm{x}$ & $\mathrm{x}$ \\
\hline
\end{tabular}


Table 5 continued

\begin{tabular}{|c|c|c|c|c|c|c|c|c|c|c|c|c|c|}
\hline Family/species & TG & 1 & 2 & 3 & 4 & 5 & 6 & 7 & 8 & 9 & 10 & 11 & 12 \\
\hline $\begin{array}{l}\text { Pomacanthus zonipectus } \\
\text { Pomacentridae }\end{array}$ & $\mathrm{O}$ & & & $\mathrm{x}$ & $\mathrm{x}$ & $\mathrm{x}$ & $\mathrm{x}$ & & & & $\mathrm{x}$ & & \\
\hline Abudefduf concolor & $\mathrm{O}$ & & & & & & $\mathrm{x}$ & & & & & & \\
\hline A. troschelii & $\mathrm{O}$ & & & & $\mathrm{x}$ & $\mathrm{x}$ & $\mathrm{x}$ & $\mathrm{x}$ & & $\mathrm{x}$ & $\mathrm{X}$ & $\mathrm{x}$ & $\mathrm{x}$ \\
\hline Chromis atrilobata & PL & $\mathrm{x}$ & $\mathrm{x}$ & $\mathrm{x}$ & $\mathrm{x}$ & $\mathrm{x}$ & $\mathrm{x}$ & $\mathrm{x}$ & $\mathrm{x}$ & $x$ & $\mathrm{x}$ & $\mathrm{x}$ & $\mathrm{x}$ \\
\hline Microspathodon bairdii & $\mathrm{TH}$ & & & & & & $\mathrm{x}$ & $\mathrm{x}$ & & & & & \\
\hline M. dorsalis & $\mathrm{TH}$ & & & & & $\mathrm{x}$ & $\mathrm{x}$ & $\mathrm{x}$ & & $x$ & $x$ & & \\
\hline Stegastes acapulcoensis & $\mathrm{TH}$ & & & $\mathrm{x}$ & & $\mathrm{x}$ & $\mathrm{x}$ & $\mathrm{x}$ & & $\mathrm{x}$ & $\mathrm{x}$ & $\mathrm{x}$ & $\mathrm{x}$ \\
\hline $\begin{array}{l}\text { S. flavilatus } \\
\text { Rhinobatidae }\end{array}$ & $\mathrm{TH}$ & $\mathrm{x}$ & $\mathrm{x}$ & $\mathrm{x}$ & $\mathrm{x}$ & $\mathrm{x}$ & $\mathrm{x}$ & $\mathrm{x}$ & $\mathrm{x}$ & $\mathrm{x}$ & $\mathrm{x}$ & $\mathrm{x}$ & $\mathrm{x}$ \\
\hline $\begin{array}{l}\text { Zapteryx exasperata } \\
\text { Scaridae }\end{array}$ & MI & & & $\mathrm{x}$ & & & & & & & & & \\
\hline Scarus compressus & RH & & & & & & $\mathrm{X}$ & & $\mathrm{x}$ & & & $\mathrm{x}$ & \\
\hline S. ghobban $^{\mathrm{a}}$ & $\mathrm{RH}$ & $\mathrm{x}$ & $\mathrm{x}$ & $\mathrm{X}$ & $\mathrm{x}$ & $\mathrm{x}$ & $\mathrm{x}$ & $\mathrm{x}$ & $\mathrm{x}$ & $x$ & $\mathrm{x}$ & $\mathrm{x}$ & $\mathrm{x}$ \\
\hline S. perrico & RH & & & & & $\mathrm{x}$ & $\mathrm{x}$ & & $\mathrm{x}$ & & & & $\mathrm{x}$ \\
\hline $\begin{array}{l}\text { S. rubroviolaceus } \\
\text { Sciaenidae }\end{array}$ & $\mathrm{RH}$ & $\mathrm{x}$ & $\mathrm{x}$ & $\mathrm{x}$ & $\mathrm{x}$ & $\mathrm{x}$ & $\mathrm{x}$ & $\mathrm{x}$ & $\mathrm{x}$ & $\mathrm{x}$ & $\mathrm{x}$ & $\mathrm{x}$ & $\mathrm{x}$ \\
\hline $\begin{array}{l}\text { Pareques viola } \\
\text { Scorpaenidae }\end{array}$ & $\mathrm{C}$ & & & & $\mathrm{x}$ & & & & & & & & \\
\hline $\begin{array}{l}\text { Scorpaena plumieri mystes } \\
\text { Serranidae }\end{array}$ & $\mathrm{C}$ & $\mathrm{x}$ & $\mathrm{x}$ & $\mathrm{x}$ & & & $\mathrm{x}$ & $\mathrm{x}$ & & $\mathrm{x}$ & $\mathrm{x}$ & & \\
\hline Alphestes immaculatus & $\mathrm{C}$ & & & & & & & & $\mathrm{x}$ & & & & \\
\hline Dermatolepis dermatolepis & $\mathrm{C}$ & & & & & & & $\mathrm{x}$ & & $\mathrm{x}$ & & & \\
\hline Epinephelus labriformis & $\mathrm{C}$ & & & $\mathrm{x}$ & $\mathrm{x}$ & $\mathrm{x}$ & $\mathrm{X}$ & $\mathrm{x}$ & $\mathrm{x}$ & $\mathrm{x}$ & $\mathrm{x}$ & $\mathrm{x}$ & \\
\hline Cephalopholis panamensis & $\mathrm{C}$ & & & $\mathrm{x}$ & $\mathrm{x}$ & $\mathrm{x}$ & $\mathrm{x}$ & $\mathrm{x}$ & $\mathrm{x}$ & $\mathrm{x}$ & $\mathrm{x}$ & $\mathrm{x}$ & \\
\hline Mycteroperca xenarcha & $\mathrm{C}$ & & & & $\mathrm{x}$ & & & & & & & & \\
\hline Paranthias colonus & PL & $x$ & $\mathrm{x}$ & $\mathrm{x}$ & $\mathrm{x}$ & & & $\mathrm{x}$ & $\mathrm{x}$ & $x$ & $x$ & & \\
\hline Serranus psittacinus & $\mathrm{C}$ & $\mathrm{x}$ & $\mathrm{x}$ & $\mathrm{x}$ & $\mathrm{x}$ & $\mathrm{x}$ & $\mathrm{x}$ & $\mathrm{x}$ & $\mathrm{x}$ & $\mathrm{x}$ & $\mathrm{x}$ & $\mathrm{x}$ & $\mathrm{x}$ \\
\hline Pseudogramma thaumasium & $\mathrm{C}$ & & & & & & & & $\mathrm{x}$ & & & & \\
\hline Rypticus bicolor & $\mathrm{C}$ & & & $\mathrm{x}$ & $\mathrm{x}$ & & & $x$ & $\mathrm{x}$ & $\mathrm{x}$ & $\mathrm{x}$ & & \\
\hline $\begin{array}{l}R . \text { nigripinnis } \\
\text { Syngnathidae }\end{array}$ & $\mathrm{C}$ & & & & & & & & $\mathrm{x}$ & & & & \\
\hline $\begin{array}{l}\text { Doryrhamphus excisus } \\
\text { Synodontidae }\end{array}$ & $\mathrm{C}$ & & & & & $\mathrm{x}$ & & & $\mathrm{x}$ & $\mathrm{x}$ & $\mathrm{x}$ & & $\mathrm{x}$ \\
\hline Synodus lacertinus & $\mathrm{C}$ & & & & & & $\mathrm{x}$ & & & $\mathrm{x}$ & & & \\
\hline $\begin{array}{l}\text { Synodus sechurae } \\
\text { Tetraodontidae }\end{array}$ & $\mathrm{C}$ & $\mathrm{x}$ & & $\mathrm{x}$ & & $\mathrm{x}$ & & & $\mathrm{x}$ & & & & \\
\hline Arothron hispidus ${ }^{\mathrm{a}}$ & $\mathrm{O}$ & $\mathrm{x}$ & $\mathrm{x}$ & $\mathrm{x}$ & $\mathrm{x}$ & & & & $\mathrm{x}$ & & $\mathrm{x}$ & & $\mathrm{x}$ \\
\hline Arothron meleagris ${ }^{\mathrm{a}}$ & $\mathrm{O}$ & $\mathrm{x}$ & $\mathrm{x}$ & & $\mathrm{x}$ & $\mathrm{x}$ & $\mathrm{x}$ & $\mathrm{x}$ & $\mathrm{x}$ & $\mathrm{x}$ & $\mathrm{x}$ & $\mathrm{x}$ & $\mathrm{x}$ \\
\hline $\begin{array}{l}\text { Canthigaster punctatissima } \\
\text { Tripterygiidae }\end{array}$ & $\mathrm{O}$ & $\mathrm{x}$ & $\mathrm{x}$ & $\mathrm{x}$ & $\mathrm{x}$ & $\mathrm{x}$ & $\mathrm{x}$ & $\mathrm{x}$ & $\mathrm{x}$ & $\mathrm{x}$ & $\mathrm{x}$ & $\mathrm{x}$ & $\mathrm{x}$ \\
\hline Axoclinus lucillae & MI & & & & & & & $\mathrm{x}$ & $\mathrm{x}$ & & $\mathrm{x}$ & & \\
\hline $\begin{array}{l}\text { Lepidonectes clarkhubbsi } \\
\text { Urolophidae }\end{array}$ & MI & & & & & & $\mathrm{x}$ & & & & & & \\
\hline $\begin{array}{l}\text { Urobatis halleri } \\
\text { Zanclidae }\end{array}$ & MI & & & $\mathrm{x}$ & & & & & $\mathrm{x}$ & & & & \\
\hline Zanclus cornutus $^{\mathrm{a}}$ & SI & & & & & $\mathrm{X}$ & & & & $x$ & $\mathrm{x}$ & & $\mathrm{x}$ \\
\hline
\end{tabular}

${ }^{a}$ Indo-Pacific species

${ }^{\mathrm{b}}$ Circumtropical species (Atlantic and Pacific)

${ }^{\mathrm{c}}$ Species from both sides of the Isthmus of Panama (Edgar et al. 2004; Robertson et al. 2004; Robertson and Allen 2002)

planktivores seems to be lower in SBC (tidal variations of about $1.7 \mathrm{~m}$ ) in comparison with GCH (tidal variations between 3 and $4 \mathrm{~m}$ ), Gulf of Papagayo, Costa Rica (tidal variation max $2.7 \mathrm{~m}$ ) and Gorgona Island, Colombia (4 m) (Zapata and Morales 1997; ArburtoOropeza and Balart 2001; Dominici-Arosemena et al. 2005; Prahl et al. 1979; this study). Future research is still necessary to distinguish the effects of food and the effect of currents at global and local scales. Planktivores may be abundant because they swim better and spend their time in the water column, or because there is a high abundance of plankton in such areas. This makes it difficult to separate the two effects that are inextricably interlinked (D.R. Robertson, personal 
Table 6 Numbers of reef fish species found in different geographical regions in the Tropical Eastern Pacific (TEP); relative coral or rocky character of reef habitats considered in the surveys: *low, **medium, *** important

\begin{tabular}{|c|c|c|c|c|}
\hline Location & $\begin{array}{l}\text { Species } \\
\text { number }\end{array}$ & $\begin{array}{l}\text { Coral } \\
\text { reef }\end{array}$ & $\begin{array}{l}\text { Rocky } \\
\text { reef }\end{array}$ & Reference \\
\hline Galapagos Islands, Ecuador & 175 & $*$ & $* * *$ & Edgar et al. (2004) \\
\hline Bahía Honda, Panama & 126 & $* *$ & $* * *$ & This study \\
\hline $\begin{array}{l}\text { Clipperton Island, France, } \\
1,300 \mathrm{~km} \text { southwest of Mexico }\end{array}$ & 115 & $* *$ & $* * *$ & Allen and Robertson (1997) \\
\hline Gulf of Papagayo, Costa Rica & 78 & $*$ & $* *$ & Dominici-Arosemena et al. (2005) \\
\hline Gulf of California, Mexico & 74 & - & $* * *$ & Arburto-Oropeza and Balart (2001) \\
\hline Gorgona Island, Colombia & 71 & $* *$ & $*$ & Zapata and Morales (1997) \\
\hline Manuel Antonio, Costa Rica & 39 & _- & $* * *$ & Phillips and Perez-Cruet (1984) \\
\hline
\end{tabular}

communication; Genin et al. 2005). Comparing studies from different locations, herbivores show low densities in all TEP regions, but in GCH their abundance tends to increase. This may be related to the use of low quality protein content food sources as algae in warmer and stable regions (Floeter et al. 2004; Harmelin-Vivien 2002). Further studies on how the relative importance of different trophic and mobility groups in reef fish assemblages varies with latitude in the TEP are still necessary (Floeter et al. 2004).

\section{Conservation issues}

$\mathrm{BH}$ is close to the former presidium in Coiba Island, an isolated region with low human population density. It has not been subjected to strong anthropogenic disturbances as yet. Due to the closing of the Coiba presidium (August 2004) and the increasing importance as a tourist destination, human activities such as artisanal fishery, sport fishing and diving activities are bound to increase. Fishes of 28 species of commercial interest have been reported in the $\mathrm{GCH}$, particularly in the National Park. Prior to this study, this region had lacked baseline data that could be used to plan and manage a sustainable fishery (Vega and Villarreal 2003). There are plans by the UNESCO to declare the Coiba National Park as a world patrimony. But BH does not form part of the Coiba National Park and, while fishery regulations are being developed by the National Environmental Authority (ANAM) for the National Park, as yet no management measures have been elaborated for the regions close to the mainland (Vega Angel, personal communication). The most populated centres of the $\mathrm{BH}$ region are around the town Pixvae, but the construction of tourist hotels with a high demand for infrastructure and seafood, and this great impact on the coastline and its habitats is to be expected in the near future. This is expected to go along with the development of tourism in the Coiba National Park. The reduction of the three-dimensional habitat structure has been identified as one cause for the shift in species composition (McKenna 1997), and there have been few repeated cases of blast fishing (personal observation). BH and the Coiba National Park are isolated but interconnected sites, with probably the most diverse fish communities in the continental TEP, and the importance of this region has as yet not been sufficiently acknowledged. Our results confirm that it may also be the most important refuge for benthic organisms.

Based on the results of this study the following measures are recommended: (1) Pocilloporid reefs and shallow coral-rocky zones should be protected as nursery areas for juvenile fish, and protection should not only be provided for the National Park of Coiba Island but also in regions that are close to the mainland. (2) Tourists and locals should be trained to not destroy or extract the benthic flora and fauna (through destructive fishing or irresponsible diving practices that may increase from low to extreme levels due to missregulations and lack of control). This should include a well organized monitoring by the authorities. (3) A permanent protection should be applied to areas inside and outside of the National Park, with special attention paid to areas of high diversity of predators (also rockycomplex zones) that form part of the secondary and tertiary consumers in the trophic chain. Due to its isolation, the GCH may be one of the few coastal regions of the TEP where the trophic web is still relatively pristine with a balance between herbivorous and carnivorous fish guilds. This fragile equilibrium would be highly affected if fishing pressure was to build up. (4) Reef areas that represent important ecosystems in the region should be delimited to prevent anchorage of boats.

In addition, there may be other anthropogenic impacts to this area in the future, particularly the expected increase in sediment deposition on the reefs caused by the construction of new infrastructure, hotels and houses in the area.

Acknowledgements This research was sponsored by the Smithsonian Tropical Research Institute (STRI), the German Academic Exchange Service (DAAD) and the Bahía Honda project-Liquid Jungle lab (LJL) research station, and was per- 
formed in cooperation with the Centre for Marine Tropical Ecology (ZMT) and The Project Aware Foundation (PADI). We thank Ross Robertson for his advice at STRI and Mr. Jean Pigozzy for giving us the opportunity to conduct this research at Liquid Jungle Lab. Guilherme Vasconcellos, Irving Bethancourt, and Nina Kriegish helped on field and data management. We also thank Carlos L. Ferreira, Sergio Floeter, Suzanne Lao, Tom Nicolai, Denise Pope, Fernando Zapata, Luis D'Croz, Carlos Jiménez, Jorge Cortés, Hector Guzmán, Carlos Guevara, Marc Kochzius, Ghislain Rompré, Werner Ekau, Marc Taylor, Sebastian Ferse, Coralie D'lima, Paul Zachos, Ismael NúñezRiboni, Friedemann Keyl and Juan Maté for advice offered. Additionally we thank Jaime Andrés Cabrera, María Patricia Castantes (LJL), Christa Müller, Silke Meyerholz, Andreas Hanning, Kai Bergmann, Stefanie Bröhl, Dieter Peterke, Petra Käpnick (ZMT), Harry Barnes, Xenia Saavedra, Adriana Bilgray, Marissa Batista, Ernesto Peña, Edgardo Ochoa, Reynaldo Tapia, Alejandro Arze and Mercedes Denis (STRI), for logistic and administrative support. Map and profile figures were drawn by Marco Luque Parigi.

\section{References}

Allen GA, Robertson DR (1997) An annotated checklist of the fishes of Clipperton Atoll, tropical eastern Pacific. Rev Biol Trop 45:813-843

Almany GR (2004a) Priority effects in coral reef fish communities of the Great Barrier Reef. Ecology 85:2872-2880

Almany GR (2004b) Differential effects of habitat complexity, predators and competitors on abundance of juvenile and adult coral reef fishes. Oecologia 141:105-113

Arburto-Oropeza O, Balart E (2001) Community structure of reef fish in several habitats of a rocky reef in the Gulf of California. Mar Ecol 22:283-305

Bay LK, Jones GP, McCormick MI (2001) Habitat selection and aggression as determinants of spatial segregation among damselfish on a coral reef. Coral Reefs 20:289-298

Bellwood DR, Wainwright PC, Fulton CJ, Hoey A (2002) Assembly rules and functional groups at global biogeographical scales. Funct Ecol 16:557-562

Bellwood DR (1998) What are reef fishes? Comment on the report by D.R. Robertson: do coral reef fish faunas have a distinctive taxonomic structure? (Coral Reefs 17:179-186) Coral Reefs 17:187-189

Bellwood DR, Hughes TP (2001) Regional-scale assembly rules and biodiversity of coral reefs. Science 292:1532-1534

Bellwood DR, Wainwright PC (2001) Locomotion in labrid fishes: implications for habitat use and cross-shelf biogeography on the Great Barrier Reef. Coral Reefs 20:139-150

Bellwood DR,Wainwright PC (2002) The history and biogeography of fishes on coral reefs. In: Sale PF (ed) Coral reef fishes. Dynamics and diversity in a complex ecosystem. Academic, San Diego, pp 5-32

Bermingham E, McCafferty S, Martin A (1997) Fish biogeography and molecular clocks: perspectives from the Panamanian Isthmus. In: Kocher $\mathrm{T}$, Stepien $\mathrm{C}$ (eds) Molecular systematics of fishes. Academic, New York, pp 113-126

Beukers-Stewart BD, Jones GP (2004) The influence of prey abundance on the feeding ecology of two piscivorous species of coral reef fish. J Exp Mar Biol Ecol 299:155-184

Bradbury RH, Young PC (1981) The effects of a major forcing function, wave energy, on a coral reef ecosystem. Mar Ecol Prog Ser 5:229-241
Briggs JC (1995) Global biogeography. Developments in paleontology and stratigraphy, 14th edn. Elsevier, Amsterdam

Cardiel JM, Castroviejo S, Velayos M (1997) Parque Nacional de Coiba: El Medio Físico. In: Castroviejo S (ed) Flora y fauna del Parque Nacional de Coiba (Panamá). Agencia Española de Cooperación Internacional-RJB, Madrid, pp 75-106

Caribbean Coastal Marine Productivity (CARICOMP) (2001) Methods manual levels 1 and 2. Manual of methods for mapping and monitoring of physical and biological parameters in the coastal zone of the Caribbean. University of the West Indies Mona, Kingston Jamaica and Florida Institute of Oceanography

Cortés J (1990) The coral reefs of Golfo Dulce, Costa Rica: distribution and community structure. Atoll Res Bull 344:136

Cortés J (1993) Comparison between Caribbean and eastern Pacific coral reefs. Rev Biol Trop 41(Suppl 1):10-21

Cortés J (1997) Biology and geology of Eastern Pacific Reefs. Coral Reefs 16(Suppl):S39-S46

D'Croz L, Mate JL (2004) Experimental responses to elevated water temperature in genotypes of the reef coral Pocillopora damicornis from upwelling and non-upwelling environments in Panama. Coral Reefs 23:473-483

D'Croz L, Robertson DR (1997) Coastal ocanographic conditions affecting coral reefs on both sides of the Isthmus of Panama. In: Proceedings of the 8th international Coral Reef symposium, vol 2, pp 2053-2058

Dominici-Arosemena A, Wolff M (2005) Reef fish community structure in Bocas del Toro (Caribbean, Panama) along spatial scales and gradients in habitat complexity. Caribb J Sci 41:613-637

Dominici-Arosemena A, Brugnoli-Olivera E, Cortés-Nuñez J, Molina-Ureña H, Quesada-Alpizar M (2005) Community structure of Eastern Pacific Reef fishes (Gulf of Papagayo, Costa Rica). Rev. Tecnociencia, FCNET, Univ. Panamá, vol 7, pp 19-41

Edgar GJ, Banks S, Fariña JM, Calvopiña M, Martínez C (2004) Regional biogeography of shallow reef fish and macroinvertebrate communities in the Galapagos archipelago. J Biogeogr 31:1107-1124

English S, Wilkinson C, Baker V (1994) Survey manual for tropical marine resources. Australian Institute of Marine Science, Townsville

Ferreira CEL, Gonçalves JEA, Coutinho R (2001) Community structure of fishes and habitat complexity in a tropical rocky shore. Environ Biol Fish 61:353-369

Ferreira CEL, Floeter SR, Gasparini JL, Ferreira BP, Joyeux JC (2004) Trophic structure patterns of brazilan reef fishes: a latitudinal comparison. J Biogeogr 31:1-13

Floeter SR, Gasparini JL (2000) The southwestern Atlantic reef fish fauna: composition and zoogeographic patterns. J Fish Biol 56:1099-1114

Floeter SR, Ferreira CEL, Dominici-Arosemena A, Zalmon I (2004) Latitudinal gradients in Atlantic reef fish communities: trophic structure and spatial use patterns. J Fish Biol 64:1-20

Fulton CJ, Bellwood DR (2002) Ontogenetic habitat use in labrid fishes: an ecomorphological perspective. Mar Ecol Prog Ser 236:255-262

Fulton CJ, Bellwood DR,Wainwright PC (2005) Wave energy and swimming performance shape coral reef fish assemblages. Proc R Soc Lond B 272:827-832

García-Chartron JA, Pérez-Ruzafa A (2001) Spatial pattern and the habitat structure of a Mediterranean rocky reef fish local assemblage. Mar Biol 138:917-934 
Genin A, Jaffe J, Reef R, Richter C, Franks P (2005) Swimming against the flow: a mechanism of zooplankton aggregation. Science 308:860-862

Glynn PW, Maté JL (1997) Field guide to the Pacific coral reefs of Panamá. In: Proceedings of 8th international Coral Reef symposium, vol 1, pp 145-66

Harmelin-Vivien M (2002) Energetics and fish diversity on coral reefs. In: Sale PF (ed) Coral Reef fishes: dynamics and diversity in a complex ecosystem. Academic, San Diego, pp 265-274

Hastings PA, Robertson DR (2001) Systematics of tropical eastern Pacific fishes. Rev Biol Trop 49(Suppl 1):209

Khalaf MA, Kochzius M (2002) Community structure and biogeography of shore fishes in the Gulf of Aqaba, Red Sea. Helgol Mar Res 55:252-284

Kwiecinski B, Chial ZB (1983) Algunos aspectos de la oceanografía del Golfo de Chiriquí, su comparación con el Golfo de Panamá. Rev Biol Trop 31:323-325

Luckhurst BE, Luckhurst K (1978) Analysis of the influence of substrate variables on coral reef fish communities. Mar Biol 49:317-323

McKenna J (1997) Influence of physical disturbance on the structure of Coral Reef Fish assemblages in the dry tortugas. Caribb J Sci 33:82-97

Mora C, Robertson DR (2005) Factors shaping the range size frequency distribution of fishes in the Tropical Eastern Pacific. J Biogeogr 32:277-286

Mora C, Chittaro PM, Sale PF, Kritzer JP, Ludsin SA (2003) Patterns and processes in reef fish diversity. Nature 421:933936

NOOA/NOS (2006) Water level tidal predictions. Tidal station locations and ranges. http://tidesandcurrents.nooa.gov

Palumbi SR (1997) Molecular biogeography of the Pacific. Coral Reefs 16:S47-S52

Paulay G (1996) Dynamic clams: changes in the bivalve fauna of Pacific islands as a result of sea level fluctuations. Am Malacol Bull 12:45-57

Phillips PC, Perez-Cruet MJ (1984) A comparative survey of reef fishes in Caribbean and Pacific Costa Rica. Rev Biol Trop 32:95-102

Pielou EC (1975) Ecological diversity. Wiley, New York

Prahl H, Guhl F, Grogl M (1979) Gorgona. Futura, Bogotá, 279 p

Quesada-Alpízar M, Morales-Ramírez A (2004) Comportamiento de las masas de agua en el Golfo Dulce durante un periodo El Niño (1997-1998). Rev Biol Trop 52:95-103

Roberts MR, Ormond RFG (1987) Habitat complexity and coral reef diversity and abundance on Red Sea fringing reefs. Mar Ecol Prog Ser 41:1-8
Robertson DR (1998) Do coral-reef fish faunas have a distinctive taxonomic structure? Coral Reefs 17:1-8

Robertson DR, Allen GR (2002) Shore fishes of the tropical eastern Pacific: an information system. Smithsonian Tropical Research Institute, Balboa, Panamá

Robertson DR, Grove JS, McCosker JE (2004) Tropical transpacific shore fishes. Pac Sci 58:507-565

Rogers CS, Garrison G, Grober R, Hillis ZM, Franke MA (1994) Coral reef monitoring manual for the Caribbean and Western Atlantic. Southern Regional Office National Park Service. The Nature Conservancy WWF

Sluka RD, Miller MW (2001) Herbivorous fish assemblages and herbivory pressure on Laamu Atoll, Republic of Maldives. Coral Reefs 20:255-262

Springer VG, Williams JT (1994) The Indo-West Pacific blenniid fish genus Istiblennius reappraised: a revision of Istiblennius, Blenniella, and Paralticus, new genus. Smithson Contrib Zool 565:1-193

Ter Braak CJF, Verdonschot PFM (1995) Canonical correspondance analysis and related multivariate methods in aquatic ecology. Aquat Sci 57:255-289

Thresher RE (1983) Environmental correlates of the distribution of planktivorous fishes in the One Tree Reef Lagoon. Mar Ecol Prog Ser 10:137-145

Vega AJ, Villarreal N (2003) Peces asociados a arrecifes y manglares en el Parque Nacional Coiba. Rev. Tecnociencia, FCNET, Univ. Panamá, vol 5(1), pp 65-74

Veron JEN (1995) Corals in space and time. Cornell University Press, Ithaca

Wilson MEJ, Rosen BR (1998) Implications of the paucity of corals in the Paleogene of SE Asia: plate tectonics or Centre of Origin? In: Hall R, Holloway JD (eds) Biogeography and geological evolution of SE Asia. Backhuys Publishers, Leiden, pp 165-195

Wolff M, Alarcón E (1993) Structure of a scallop Argopecten purpuratus (Lamarck, 1819) dominated subtidal macroinvertebrate assemblage in Northern Chile. J Shellfish Res 12:295-304

Wolff M, Hartmann H, Koch V (1996) A pilot trophic model for Golfo Dulce, a fjord-like tropical embayment, Costa Rica. Rev Biol Trop 44(Suppl 3):215-231

Zapata FA, Morales A (1997) Spatial and temporal patterns of fish diversity in a coral reef at Gorgona Island, Colombia. In: Proceedings of the 8th international Coral Reef symposium, vol 1, pp 1029-1034

Zar JH (1996) Biostatistical analysis, 3rd edn. Prentice Hall, Upper Saddle River 